Latvijas Lauksaimniecības universitāte Latvia University of Life Sciences and

\title{
Technologies
}

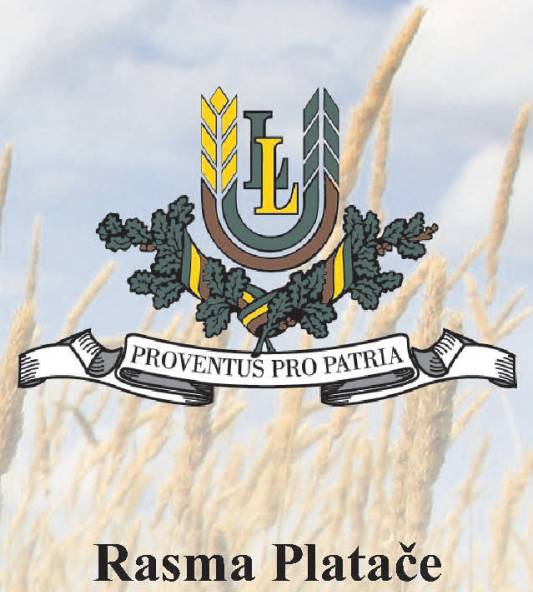

ZĀLAUGU BIOMASAS IEGUVE CIETĀ KURINĀMĀ RAŽOŠANAI

\section{OBTAINING OF GRASS BIOMASS FOR THE PRODUCTION OF SOLID FUEL}

\section{Promocijas darba KOPSAVILKUMS}

Dr. agr. zinātniskā grāda iegūšsanai

for the scientific degree of Dr.agr.

Jelgava 2018 
Latvijas Lauksaimniecības universitāte Latvia University of Life Sciences and Technologies

Lauksaimniecības fakultāte Faculty of Agriculture

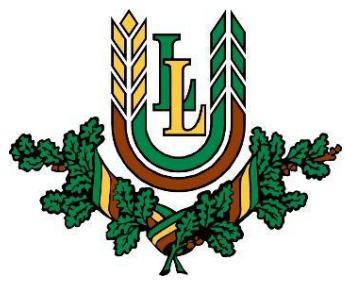

Mg. sc. env. Rasma Platače

\section{ZĀLAUGU BIOMASAS IEGUVE CIETĀ KURINĀMĀ RAŽOŠANAI}

\section{OBTAINING OF GRASS BIOMASS FOR THE PRODUCTION OF SOLID FUEL}

Promocijas darba KOPSAVILKUMS

Dr. agr. zinātniskā grāda iegūšanai

SUMMARY

of the Doctoral Thesis for the scientific degree of Dr. agr.

Paraksts / Signature

Jelgava

2018 
Darba zinātniskais vadītājs / Scientific supervisor Profesors, Dr. agr. Aleksandrs Adamovičs

Darba recenzenti / Profesors emeritus Dr. agr. Dainis Lapiņ̌s Reviewers Profesors Dr. sc. ing. Aivars Kaķītis Profesore Dr. biol. Anita Osvalde

Promocijas darba aizstāvēšana paredzēta Latvijas Lauksaimniecības universitātes Lauksaimniecības nozares Laukkopības apakšnozares promocijas padomes atklātā sēdē 2018. gada 28. augustā, plkst. 10.00, LLU 123. auditorijā, Lielā ielā 2, Jelgavā.

The defence of the Doctoral Thesis in an open session of the Promotion Board of Agriculture will be held on August 28, 2018, at 10:00, Room 123, Latvia University of Lifes Sciences and Technologies, Liela iela 2, Jelgava, Latvia.

Ar promocijas darbu var iepazīties LLU Fundamentālajā bibliotēkā Jelgavā, Lielā ielā 2.

The Thesis is available at the Fundamental Library of Latvia University of Life Sciences and Technologies, Liela iela 2, Jelgava, Latvia.

Atsauksmes sūtīt Lauksaimniecības zinātṇu nozares Laukkopības apakšnozares promocijas padomes sekretārei $D r$. agr. Maijai Ausmanei, Lielā iela 2, Jelgava, LV-3001.

References are welcome to be sent to Dr. agr. Maija Ausmane, the Secretary of the Promotion Board, Latvia University of Life Sciences and Technologies, Liela iela 2, Jelgava, LV-3001, Latvia.

DOI: $10.22616 /$ lluthesis/2018.010 


\section{SATURS / CONTENTS}

PĒTĪJUMU AKTUALITĀTE

PĒTĪJUMU APSTĀKL̨I UN METODES 6

PĒTİJUMU REZULTĀTI

1. Mēslojuma ietekmes uz stiebrzāḷlu sausnas ražu efektivitāte 10

2. Slāpekḷa mēslojuma izmantošanas efektivitāte stiebrzāḷu audzēšanā $\quad 16$

3. Stiebrzāḷ biomasas kurināmā kvalitātes rādītāju novērtēšana 17

4. Biomasas kurināmā sadegšanas parametri 22

5. Biomasas kurināmā izejvielu energétiskā vērtība 23

6. Biomasas kurināmā izejvielu ražošanas izmaksas 25

SECINĀJUMI $\quad 28$

PRIEKŠLIKUMI $\quad 30$

THE TOPICALITY OF THE RESEARCH 30

STUDY CONDITIONS AND METHODS 32

RESULTS

1. The Effect of Fertilizer on Grass Dry Matter Yield 35

2. Fertilizer Efficiency in Grass Growing 38

3. Evaluation of Grass Biomass Fuel Quality Indicators 38

4. Biomass Combustion Parameters 43

5. Energy Value of Biomass Fuel Raw Materials 44

6. Production Costs of Biomass Fuel Raw Materials 44

CONCLUSIONS 46

PROPOSALS $\quad 47$

PROMOCIJAS DARBA APROBĀCIJA /

APPROBATION OF THE DOCTORAL THESIS 48 


\section{PĒTĪJUMU AKTUALITĀTE}

Šobrīd biomasas energétiskais potenciāls tiek lēsts ap 10-14\% no kopējā enerğijas patēriņa pasaulē (Putun, Ozcan, Gercel et al., 2011; Offermann, Brunner, Barnthaler et al., 2011; Venkata, 2014). Pētījumi par atjaunojamo energoresursu izmantošanu ir aktuāli visā pasaulē, t. sk. Eiropā un Latvijā.

Jaunākajos pētījumos daudzgadīgo zālaugu izmantošana biokurināmā ražošanai tiek atzīta par perspektīvāku salīdzinājumā ar viengadīgajiem kultūraugiem (Jasinskas, Zaltauskas, Kryzeviciene, 2008; Prochnow, Heiermann, Plöchl et al., 2009). Rezultāti liecina, ka kurināmā siltumspēja ir atkarīga no zālaugu sugu daudzveidības (Khalsa, 2013).

Šajā pētījumā apskatīta tikai neliela dą̣a no daudzgadīgo zālaugu sugu biomasas veidiem, proti, - stiebrzāles, kas tiek uzskatītas par daudzsološāko atjaunojamo resursu avotu un kam piemīt atbilstošas enerḡetiskās īpašības un pietiekami augsta siltumspēja. Stiebrzāl̨u biomasu var izmantot cietā kurināmā granulu un brikešu ražošanā. Stiebrzāḷu biomasas mīnuss ir augstais pelnu iznākums; tāpat tās fizikālās, mehāniskās un ḳīmiskās īpašības ir atkarīgas no šķirnes, augsnes un klimatiskajiem apstākḷiem, izmantoto mēslošanas līdzekḷu veidiem un daudzuma, augu blīvuma un novākšanas laika. Svarīgi ir noskaidrot konkrētu stiebrzāḷ sugu biomasas energèetisko īpašību atbilstību vietējiem apstākḷiem, lai atrastu optimālo biomasas pielietojuma variantu (tīrā veidā vai maisījumos) cietā kurināmā ražošanai. Promocijas darbā skaidrota Latvijas apstākḷiem piemērotāko stiebrzāļu sugu izmantošana biomasas maisījumu veidošanai ar koksni un analizēta cietā kurināmā enerǵêtiskā vērtība, n̦emot vērā arī ekonomisko aspektu.

Bioenerḡêtikas vajadzībām no zālaugu sugām piemērotākais ir miežabrālis (Phalaris arundinacea (L.) Raush.), niedru auzene (Festuca arundinacea Schreb.), auzeņairene ( $\times$ Festulolium Asch \& Graebn.), parastā kamolzāle (Dactylis glomerata L.) un citas stiebrzāḷ sugas.

Salīdzinājumā ar citiem alternatīvo enerğiju veidiem granulētā zālaugu biomasa var kḷūt par nozīmīgu kurināmā avotu siltumenergijas ražošanai Latvijā. Piemēram, Latvijā ir pietiekami liels kurināmās koksnes izmantošanas potenciāls, tomēr koksnes resursi nākotnē var strauji sarukt, jo tie lēni atjaunojas (atkarībā no kokaugu sugas vismaz 20-60 gadu laikā). Stiebrzālēm kā atjaunojamam enerǵijas avotam ir liels potenciāls, jo izmantošanai noderīgā biomasa izaug vienā veǵetācijas sezonā un to var apstrādāt un patērēt izaudzēšanas vietā. Stiebrzāles siltumenerğijas ražošanai Latvijā gandrīz netiek izmantotas, tāpēc promocijas darba ietvaros, lai iegūtu Latvijas apstākḷiem optimāla sastāva un augstas energoietilpības biokurināmo, autore pētīja dažādu proporciju (1/3,1/1 un 3/1) koksnes un stiebrzāḷ biomasas maisījumus granulu ražošanai.

Darba hipotēze. Stiebrzāḷ biomasa un tās maisījumi ar koksni pēc siltumtehniskajiem parametriem ir piemēroti cietā kurināmā ražošanai. 
Darba mērḳis: novērtēt stiebrzāḷu biomasas izmantošanas iespējas cietā kurināmā ražošanai.

\section{Darba uzdevumi:}

1) izvērtēt stiebrzāḷu sugu ražu, lietojot dažādas slāpekḷa mēslojuma normas;

2) noteikt stiebrzāḷu biomasas siltumtehniskos parametrus un izvērtēt to atbilstību cietā kurināmā ražošanai;

3) noskaidrot ieteicamās stiebrzāḷu un koksnes biomasas proporcijas granulu veidošanai;

4) noteikt energiijas saturu stiebrzāl̨u, koksnes un to maisījumu biomasām un novērtēt kurināmā pašizmaksu.

\section{Pētîjuma novitāte:}

- noteikta stiebrzāḷ sugu biomasas kvalitāte kurināmā ražošanai;

- $\quad$ irmo reizi analizēta stiebrzālu un koksnes biomasu maisījumu proporciju siltumtehnisko parametru atbilstība cietā kurināmā kvalitātes prasībām.

\section{Aizstāvamās tēzes:}

- $\quad$ stiebrzālēm ir labas energeetiskās īpašības un pietiekami augsta siltumspēja;

- $\quad$ stiebrzāḷu biomasu var izmantot cietā kurināmā granulu un brikešu ražošanai;

- $\quad$ saražotais energijas daudzums ir atkarīgs no stiebrzāl̨u un koksnes sugu izvēles, kā arī no to proporcijas maisījumos.

Pētījuma oriǵinalitāte. Pirmo reizi no enerǵētiskā aspekta analizēta mēslojuma ietekme uz stiebrzāḷu ražu, sausnas ḳīmisko sastāvu un energ̣êtiskajiem rādītājiem, kā arī uz šo stiebrzāḷu un koksnes biomasas maisījumiem, veidojot atškirīgas maisījumu proporcijas ar dažādu kokaugu sugu koksnēm, un uz to atbilstību biokurināmā standarta kvalitātes prasībām.

Pētījuma rezultātu praktiskā un teorētiskā nozīmība. Stiebrzālēm, salīdzinot ar kokaugiem, ir savs augšanas ritms, prasības pret augšanas vidi un mēslojumu, un tās atškiriras ar siltumtehniskajām īpašībām, ko ietekmē izvēlētā agrotehnika un novākšanas veids. Pētījumā iegūtie rezultāti ļauj pilnveidot stiebrzāḷu audzēšanas tehnologiju atbilstoši kurināmā kvalitātes prasībām, pieṇemt precīzāku lēmumu par attiecīgās stiebrzāḷu sugas izvēli audzēšanai konkrētos agroklimatiskajos apstākḷıs un papildina zināšanas par biokurināmā ražošanas procesa efektivitāti. Iegūtie rezultāti noder stiebrzāḷu un koksnes granulu enerǵētiskā potenciāla aprēķiniem, ņemot vērā, ka biomasas vērtība mainās atkarībā no stiebrzāḷ sugas, iestrādātā mēslojuma un attiecīgā gada meteorologisko apstākḷu īpatnībām.

Ieguvums no pētījuma rezultātiem. Pētījuma gaitā uzkrātā un aprakstītā pieredze ḷaus paplašināt stiebrzāḷ izmantošanas spektru - ne tikai kā līdz šim tradicionāli lauksaimniecībā lopbarības ieguvei, bet vēl papildus arī 
biokurināmā ražošanai. Iegūtie rezultāti uzskatāmi parāda lietderīgākos stiebrzāḷ un koksnes biomasu maisījumu veidus un to proporcijas.

\section{PĒTĪJUMU APSTĀKḶI UN METODES}

\section{Lauka izmēgeginājumi tika ierīkoti Latvijas Lauksaimniecības} universitātes (LLU) mācību un pētījumu saimniecībā „Pēterlauki” $\left(56^{\circ} 53^{\prime} \mathrm{N}\right.$, $23^{\circ} 71^{\prime}$ E) 2011. gadā. Pêtījums veikts laikā no 2012. gada līdz 2016. gadam.

Augsnes tips: velēnu karbonātu (VK; sod calcareous soil) (Endocalcaric Luvisol pēc FAO klasifikācijas). Granulometriskais sastāvs: smags putekḷu smilšmāls. Augsnes agroḳīmiskie rādītāji: $\mathrm{pH}_{\mathrm{KCl}} 6.7$ (LVS ISO 10390:2006); organiskās vielas saturs - $21 \mathrm{~g} \mathrm{~kg}^{-1}$ (pēc Tjurina metodes; LV ST ZM 80-91); fosfora saturs - $52 \mathrm{mg} \mathrm{kg}^{-1} \mathrm{P}_{2} \mathrm{O}_{5}$ (zems); kālija saturs - $128 \mathrm{mg} \mathrm{kg}^{-1} \mathrm{~K}_{2} \mathrm{O}$ (vidējs) (pēc Egnera-Rīma metodes; LV ST ZM 82-97).

Priekšaugs bija vasaras mieži, audzēti divus gadus pēc kārtas kā izlīdzinošs sējums. Pēc priekšauga novākšanas augsne tika uzarta rudenī $22 \mathrm{~cm}$ dziļi. Pavasarī, augsnei sasniedzot fizikāli mehānisko gatavību, tā vispirms tika nošlūkta, pēc tam - nokultivēta.

Izmēginājumu ierīkoja 2011. gadā ar sešām stiebrzāḷu sugām: miežabrālis (Phalaris arundinaceae (L.) Raush.), šķirne 'Marathon'; auzeņairene (× Festulolium Asch. \& Graebn.), šķirne 'Vetra'; timotiņ̌ (Phleum pratense L.), škirne 'Teicis'; pḷavas auzene (Festuca pratensis Huds.), škirne 'Vaira'; niedru auzene (Festuca arundinaceae Schreb.), šķirne 'Fawn'; un kamolzāle (Dactylis glometata L.), šķirne 'Priekulı 30'.

Stiebrzāḷ sugu izsējas norma bija 1000 dīgtspējīgu sēklu uz $1 \mathrm{~m}^{2}$ ar attiecīgo daudzumu uz 1 ha: miežabrālim $-10.0 \mathrm{~kg}$, auzeņairenei $-9.5 \mathrm{~kg}$, timotiņam - $13.0 \mathrm{~kg}$, pḷavas auzenei $-12.5 \mathrm{~kg}$, niedru auzenei $-17.0 \mathrm{~kg}$, kamolzālei - $18.0 \mathrm{~kg}$. Stiebrzāḷu sugas tika iesētas bez virsauga, ar sējmašīnu „Hēge-80” 2011. gada 10. maijā.

Visām stiebrzāḷ sugām tika izmantoti šādi mēslojuma varianti: $\mathrm{N}_{0} \mathrm{P}_{2} \mathrm{O}_{5} 0$ $\mathrm{K}_{2} \mathrm{O} 0$ - kontrole; $\mathrm{P}_{2} \mathrm{O}_{5} 80 \mathrm{~K}_{2} \mathrm{O} 120 \mathrm{~kg} \mathrm{ha}^{-1}$ - pamatmēslojums $(\mathrm{F})$; un seši pamatmēslojuma varianti ar slāpekḷa mēslojuma normām: F+30, F+60, F+90, $\mathrm{F}+120, \mathrm{~F}+150$ un $\mathrm{F}+180 \mathrm{~kg} \mathrm{ha}^{-1} \mathrm{~N}$. Minerālmēslus stiebrzāḷu sējas gadā nelietoja, bet izsēja pavasarī, veǵetācijas sākumā, attiecīgā zelmeņa izmantošanas gadā.

Izmēgénājumā kopā ierīkoti 48 varianti. Lauciṇa platība $-10 \mathrm{~m}^{2}$, ar $2 \mathrm{~m}$ platu sleju starp stiebrzāḷu sugām. Variantu izkārtojums - randomizēts.

Ražas uzskaite un paraugu sagatavošana. Ražas uzskaiti pētījuma vajadzībām sāka veikt no 2012. gada (1. zelmeņa izmantošanas gads). Turpmākie zelmeņu izmantošanas gadi bija: 2013. gads - 2. zelmeņa izmantošanas gads; 2014. gads - 3. zelmeņa izmantošanas gads; 2014. gads - 4 . zelmeņa izmantošanas gads; 2016. gads -5 . zelmeņa izmantošanas gads. Ražas 
uzskaite tika veikta, nopḷaujot zāli 5-6 cm augstumā ar kombainu „Hans-Ulrich Hege 212", un augu zal̦masas svars tika nolasīts elektroniski, nosakot katra atkārtojuma ražu uz lauka.

Katrai sugai un mēslojuma variantam trīs atkārtojumos tika noṇemti zalımasas paraugi, katrs $1.5-2.0 \mathrm{~kg}$; tos sasmalcināja $2-3 \mathrm{~cm}$ garos gabaliņos. Katram variantam sagatavoja paraugus ar $1 \mathrm{~kg}$ masu, ar precizitāti $\pm 0.01 \mathrm{~kg}$, fizikālo un ķīmisko analīžu veikšanai. Sausnas saturu zaḷmasas paraugos noteica, žāvējot tos $105^{\circ} \mathrm{C}$ temperatūrā.

Sausnas ražas katrā variantā tika izteiktas kā vidējās aritmētiskās vērtības no trīs atkārtojumiem un savā starpā salīdzinātas kā absolūtā novirze $\pm\left(\mathrm{t} \mathrm{ha}^{-1}\right)$ un relatīvā novirze (\%). Slāpekḷa mēslojuma ietekmes noskaidrošanai mēslojuma varianta faktiskās vērtības tika salīdzinātas ar (1) kontroles variantu, kurā netika lietots mēslojums, un ar (2) fona variantu $\left(\mathrm{P}_{2} \mathrm{O}_{5} 80 \mathrm{~K}_{2} \mathrm{O} 120\right)$, kurā nebija izmantots slāpekḷa mēslojums.

Meteorologisko apstākḷu raksturojums. Par laika periodu no 2011. gada 1. janvāra līdz 2016. gada 31. decembrim tika izmantoti dati par gaisa temperatūru un nokrišņu daudzumu no LLU MPS „Pēterlauki” automātiskās meteoroloǵiskās stacijas. Kārtējā gada meteorologisko datu salīdzināšanai izmantoja ilggadējos vidējos temperatūras un nokrišņu datus (norma) no Jelgavas meteostacijas.

Klimatiskie apstākḷi ietekmē stiebrzāḷ pārziemošanu un zelmeņa ataugšanu, kā arī nosaka ražas lielumu. Ziemošanas perioda garums pa gadiem svārstījās no 128 dienām 2013./2014. gadā līdz 173 dienām 2012./2013. gadā. Piecu gadu periodā tikai divas ziemas bija ar negatīvu vidējo gaisa temperatūru. Aukstākā ziema bija 2012./2013. gadā, kad vidējā gaisa temperatūra noslīdēja līdz $-2.5^{\circ} \mathrm{C}$, savukārt 2014./2015. un 2015./2016. gada ziemas bija vissiltākās, kad vidējā gaisa temperatūra sasniedza vai pārsniedza $+1.0^{\circ} \mathrm{C}$.

Veǵetācijas periodā nokrišnu daudzums 2011., 2012. un 2014. gadā, salīdzinot ar normu, atbilda ilggadēji vidēji novērotajam, bet 2013., 2015. un 2016. gadā bija ievērojami mazāks par normu.

Cietā kurināmā paraugu sagatavošana. Cietā kurināmā biomasas granulas tika veidotas no samaltas stiebrzālu un koksnes biomasas. Granulu veidošanai tika izmantoti sausi pulvera maisījumi, kuri sastāvēja no šādiem komponentiem: stiebrzāles (miežabrālis, auzeņairene, niedru auzene, timotiņ̌s, plavas auzene) un koksne (bērzs (Betula pendula Roth.), kārkls (Salix spp.), baltalksnis (Alnus incana (L.) Moench), apse (Populus tremula L.) un hibrīdapse (Populus tremuloides $\times$ Populus tremula)).

Koksnes biomasu - sausa pulvera veidā, ar dalinu diametru $<1 \mathrm{~mm}-$ ieguva no Latvijas Valsts mežzinātnes institūta (LVMI) „Silava”.

Stiebrzāḷu un koksnes pulveri sapresēja granulās ar rokas presi „IKA Werke".

Divkomponentu granulas veidoja ar šādu komponentu attiecību:

(I) proporcija 1/3 (25\% koksne $+75 \%$ stiebrzāles); 
(II) proporcija $1 / 1$ (50\% koksne $+50 \%$ stiebrzāles);

(III) proporcija 3/1 (75\% koksne $+25 \%$ stiebrzāles).

Par kontroli izmantoja vienkomponentu (100\%) granulas no stiebrzāḷu un koksnes pulvera.

Granulu energ̣ētisko vērtību aprēḳināja pēc formulas (1):

$$
Q_{k o p}=Q_{a} \cdot M_{s},
$$

kur $Q_{k o p}-$ kopējais enerǵijas daudzums, ko iegūst no 1 ha, $\mathrm{MJ}$ ha $^{-1}$;

$Q_{a}$ - biomasas sausnas augstākā siltumspēja, $\mathrm{MJ} \mathrm{kg}^{-1}$;

$M_{s}$ - no 1 ha iegūtās biomasas sausnas masa, $\mathrm{kg} \mathrm{ha}^{-1}$.

Granulu energijas pašizmaksa tika aprēkināta pēc formulas (2):

$$
p_{e}=\frac{P_{m}}{1000 \cdot Q_{a}},
$$

kur $p_{e}-$ iegūtās enerǵijas pašizmaksa (rēḳinot uz sausnu), Eur $\mathrm{MJ}^{-1}$;

$P_{m}-1$ tonnas biomasas sausnas ieguves pašizmaksa, Eur $\mathrm{t}^{-1}$;

$Q_{a}$ - biomasas sausnas augstākā siltumspēja, $\mathrm{MJ} \mathrm{kg}^{-1}$.

Lai novērtētu stiebrzālu un koksnes biomasas un to maisījumu granulu piemērotību izmantošanai par cieto kurināmo siltumenerğijas ražošanai, tika veiktas kịmisko un enerǵētisko rādītāju un īpašību analīzes. Analīzes veica LLU Agronomisko analīžu zinātniskajā laboratorijā un Atkritumproduktu un kurināmā izpētes un testēšanas laboratorijā „Virsma” ar metodēm, kas apkopotas 1. un 2. tabulā.

Ķīmisko īpašību analǐžu metodes /

\section{Methods of the Analyses of Chemical Properties ${ }^{1}$}

(LLU Agronomisko analīžu zinātniskā laboratorija / LLU Scientific Laboratory of Agronomic Analysis)

\begin{tabular}{|l|c|l|}
\hline \multicolumn{1}{|c|}{ Rādītāji / Parameters } & $\begin{array}{c}\text { Mēr- } \\
\text { vien̄̄ba } \\
\text { / Unit }\end{array}$ & \multicolumn{1}{|c|}{ Metode / Method } \\
\hline $\begin{array}{l}\text { Sausnas saturs / Dry matter } \\
\text { content }\end{array}$ & $\%$ & $\begin{array}{l}\text { Forage analyses, USA, met. } \\
2.2 .1 .1: 1993\end{array}$ \\
\hline Pelnu saturs / Ash content & $\%$ & ISO 5984:2002/Cor 1:2005 \\
\hline Slāpeklis (N) / Nitrogen & $\%$ & LVS EN ISO 5983-2:2009 \\
\hline Fosfors (P) / Phosphorus & $\%$ & $\begin{array}{l}\text { ISO 6492; spektrometrijas metode / } \\
\text { spectrometry method }\end{array}$ \\
\hline
\end{tabular}

1 LVS EN 14961-2:2011. Solid biofuels. Fuel specifications and classes. Section 2: Wood pellets for industrial use. 
1. tabulas turpinājums / Table 1 continue

\begin{tabular}{|l|c|ll|}
\hline \multicolumn{1}{|c|}{ Rādītāji / Parameters } & $\begin{array}{c}\text { Mēr- } \\
\text { vien̄iba } \\
\text { / Unit }\end{array}$ & \multicolumn{1}{|c|}{ Metode / Method } \\
\hline Kālijs (K) / Potassium & $\%$ & LVS EN ISO 6869:2002 \\
\hline Sērs (S) / Sulphur & $\%$ & $\begin{array}{l}\text { CS-500 analizatora metode / } \\
\text { analyzer method }\end{array}$ \\
\hline Ogleklis (C) / Carbon & $\%$ & $\begin{array}{l}\text { CS-500 analizatora metode / } \\
\text { analyzer method }\end{array}$ \\
\hline Celuloze / Cellulose & $\%$ & $\begin{array}{l}\text { Celuloze = ADF - lignīns / } \\
\text { Cellulose = ADF - lignin }\end{array}$ \\
\hline $\begin{array}{l}\text { Hemiceluloze / } \\
\text { Hemicellulose }\end{array}$ & $\%$ & $\begin{array}{l}\text { Hemiceluloze = NDF - ADF / } \\
\text { Hemicellulose = NDF - ADF }\end{array}$ \\
\hline Lignīns / Lignin & $\%$ & LVS EN ISO 13906:2008 \\
\hline
\end{tabular}

2. tabula / Table 2

Enerğēètisko rādītāju analī̌̌u metodes /

Analyses Methods of Energetic Parameters ${ }^{2}$

(Atkritumproduktu un kurināmā izpētes un testēšanas laboratorija „Virsma” /

Laboratory of Testing and Research of Waste Products and Fuels ,,Virsma”)

\begin{tabular}{|l|c|l|}
\hline \multicolumn{1}{|c|}{ Rādītāji / Parameters } & $\begin{array}{c}\text { Mēr- } \\
\text { vien̄̄ba / } \\
\text { Unit }\end{array}$ & \multicolumn{1}{|c|}{ Standarts / Standard } \\
\hline Mitruma saturs / Moisture content & $\%$ & ISO 589; LVS EN 14774 \\
\hline Pelnu saturs / Ash content & $\%$ & ISO 1171; LVS EN 14775 \\
\hline Hlors (Cl) / Chlorine & $\%$ & ISO 587; LVS EN 15105 \\
\hline Ūdenradis (H) / Hydrogen & $\%$ & ISO 625; LVS EN 15104 \\
\hline $\begin{array}{l}\text { Augstākā siltumspēja (Q) / Gross } \\
\text { calorific value }\end{array}$ & $\mathrm{MJ} \mathrm{kg}^{-1}$ & ISO 1928; LVS EN 14918 \\
\hline $\begin{array}{l}\text { Pelnu kušanas temperatūra } \\
\text { oksidējošā atmosfērā / Ash melting } \\
\text { temperature in oxidizing } \\
\text { atmosphere }\end{array}$ & ${ }^{\circ} \mathrm{C}$ & ISO 540; LVS EN 15370-1 \\
\hline
\end{tabular}

Pētīto stiebrzāḷu sugu biomasas kurināmā fizikālās īpašības tika novērtētas, salīdzinot ar prasībām, kas noteiktas standartā LVS EN 14961-2-2012 (LVS EN ISO 17225-6:2014) miežabrālim, bet koksnes biomasas kurināmā fizikālās īpašības tika salīdzinātas ar prasībām, kas norādītas standartā LVS EN 14961-

2 LVS EN 14961-2:2011. Solid biofuels. Fuel specifications and classes. Section 2: Wood pellets for industrial use. 
6-2012 (LVS EN ISO 17225-2:2014) veseliem kokiem bez saknēm, kā arī koku stumbriem.

Datu matemātisko apstrādi veica ar „Microsoft Excel for Windows 2000" un SPSS programmas paketēm. Ar šīm programmām iegūti arī atbilstošie koeficienti, vienādojumi un grafiskie attēli.

Iegūtos pētījuma rezultātus statistiski apstrādāja, pielietojot aprakstošās statistikas un variācijas statistikas pie $95 \%$ ticamības līmeņa, kā arī tika izmantotas, korelācijas un faktoranalīzes metodes. Veicot korelācijas analīzi, aprēḳināta empīriskā būtiskuma $p$ vērtība. Faktoru ietekmes būtiskuma novērtēšanai izmantots būtiskuma līmenis $p<0.05$. Lai noskaidrotu mainīgo faktoru ietekmi uz atkarīgo faktoru, tika izmantota multiplas lineāras regresijas analīze. Datu analīze atainota ar lineārās regresijas līknēm un vienādojumiem. Slāpekḷa mēslojuma normas lieluma ietekmi uz enerǵētisko augu produktivitāti novērtēja ar lineārās regresijas vienādojumiem un determinācijas koeficientu $\left(\mathrm{R}^{2}\right)$. Slāpekḷa mēslojuma normu ietekme uz stiebrzāḷ sausnas ražu analizēta un parādīta polinomālo sakarību veidā attiecīgo slāpekḷa normu intervālā (ayx un $b y x$ ) un aprakstīta ar polinomu lineāro definīciju apgabalu lineārajiem regresijas koeficientiem un atbilstošajiem lineārajiem regresijas vienādojumiem. Stiebrzāḷu un koksnes biomasas augstākā siltumspēja tika izmantota saražotās enerğijas daudzuma aprēḳiniem.

\section{PĒTĪJUMU REZULTĀTI}

\section{Mēslojuma ietekmes uz stiebrzāḷu sausnas ražu efektivitāte}

Visu pētījumā iekḷauto stiebrzāḷu sugu ražību ietekmēja gan attiecīgā gada klimatiskie apstākḷi, gan lietotais minerālmēslojums.

Variantā bez mēslojuma miežabrāḷa sausnas raža izmantošanas gados variēja no $3.67 \mathrm{t} \mathrm{ha}^{-1}$ līdz $5.73 \mathrm{t} \mathrm{ha}^{-1}$, turklāt tā palielinājās ar katru nākamo izmantošanas gadu; niedru auzenei sausnas raža bija no $4.23 \mathrm{t} \mathrm{ha}^{-1}$ līdz $5.51 \mathrm{t} \mathrm{ha}^{-1}$, ar maksimālo ražu 4. izmantošanas gadā; auzeņairenei - no $3.87 \mathrm{t} \mathrm{ha}^{-1}$ līdz $4.51 \mathrm{t} \mathrm{ha}^{-1}$, ar ražas maksimumu 3. izmantošanas gadā; timotinamam - no $2.99 \mathrm{t} \mathrm{ha}^{-1}$ līdz $4.38 \mathrm{t} \mathrm{ha}^{-1}$, ar augstāko sausnas ražu 3 . izmantošanas gadā; pḷavas auzenei - no $2.72 \mathrm{t} \mathrm{ha}^{-1} \mathrm{li} d z 4.01 \mathrm{t} \mathrm{ha}^{-1}$, ar ražas maksimumu 3. izmantošanas gadā; kamolzālei - no $5.18 \mathrm{t} \mathrm{ha}^{-1}$ līdz $5.27 \mathrm{t} \mathrm{ha}^{-1}$.

Slāpekḷa mēslojums visām stiebrzāḷu sugām pozitīvi ietekmēja sausnas ražas pieaugumu visos zelmeņa izmantošanas gados, taču ne vienmēr ražas pieaugums bija būtisks vai ekonomiski izdevīgs.

Slāpekḷa minerālmēslu variantos vidēji zemāko sausnas ražas līmeni uzrādīja auzeņairene $\left(6.18 \mathrm{t} \mathrm{ha}^{-1}\right)$, bet augstāko sausnas ražu - kamolzāle (9.62 t ha $\left.\mathrm{ha}^{-1}\right)$. Slāpekḷa mēslojuma lietošana stiebrzālēm vidēji visos zelmeṇa izmantošanas gados nodrošināja šādus sausnas ražas pieaugumus: kamolzālei - 
$3.48 \mathrm{t} \mathrm{ha}^{-1}(+57 \%$, salīdzinot ar variantu bez slāpekḷa mēslojuma), timotinam $2.55 \mathrm{t} \mathrm{ha}^{-1}(+51 \%)$, plavas auzenei $-2.33 \mathrm{t} \mathrm{ha}^{-1}(+52 \%)$, auzenairenei $2.24 \mathrm{t} \mathrm{ha}^{-1}(+57 \%)$, niedru auzenei $-1.99 \mathrm{t} \mathrm{ha}^{-1}(+38 \%)$, miežabrālim $1.93 \mathrm{tha}^{-1}(+37 \%)$.

Iegūtie izmēginājuma rezultāti liecina, ka niedru auzene un auzeņairene bija atsaucīgas uz slāpekḷa mēslojumu: palielinot slāpekḷa normu, arī to sausnas raža būtiski palielinājās (1. att.).

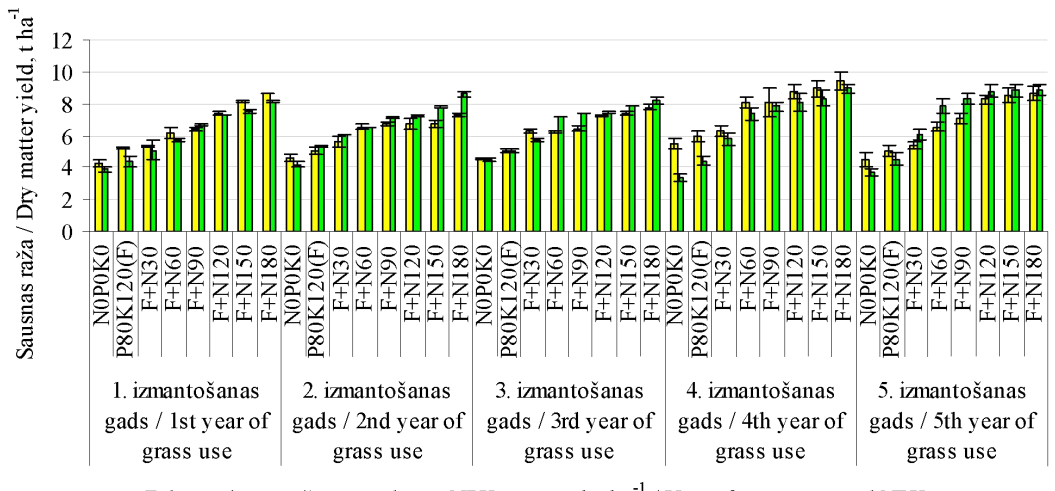

Zelmeṇa izmantošanas gads, un NPK normas, $\mathrm{kg} \mathrm{ha}^{-1}$ / Year of grass use, and NPK norms, $\mathrm{kg} \mathrm{ha}^{-1}$

$\square$ Niedru auzene / Tall fescue $\square$ Auzenairene / Festulolium

1. att. / Fig. 1. Mēslojuma ietekme uz niedru auzenes un auzeṇairenes sausnas ražu. / Effect of fertilizer on dry matter yield of tall fescue and festulolium.

Zelmeņa 1. izmantošanas gadā niedru auzenei būtisku $(p<0.05)$ ražas palielinājumu novēroja, ja tika lietota $60 \mathrm{~kg} \mathrm{ha}^{-1} \mathrm{~N}$ mēslojuma norma, - tad sausnas raža sasniedza $6.15 \mathrm{t} \mathrm{ha}^{-1}$. Turpmāka slāpekḷa normas palielināšana līdz $180 \mathrm{~kg} \mathrm{ha}^{-1} \mathrm{~N}$ sekmēja būtisku ražas pieaugumu - pat $8.64 \mathrm{t} \mathrm{ha}^{-1}$ sausnas. Arī auzeņairenei būtisks $(p<0.05)$ sausnas ražas pieaugums turpinājās līdz $180 \mathrm{~kg} \mathrm{ha} \mathrm{h}^{-1} \mathrm{~N}$ normai, nodrošinot $8.11 \mathrm{t} \mathrm{ha}^{-1}$ sausnas ražas iegūšanu. Turpmākajos gados līdz ar blīvāka zelmeņa attīstību auzeņairenei sausnas ražu $>8.0 \mathrm{t} \mathrm{ha}^{-1}$ ieguva ar mazākām slāpekḷa normām, nekā tas bija nepieciešams zelmeṇa 1. izmantošanas gadā.

Niedru auzenei 2. zelmeņa izmantošanas gadā būtisku $(p<0.05)$ ražas palielinājumu novēroja, lietojot $30 \mathrm{~kg} \mathrm{ha}^{-1} \mathrm{~N}$ normu. Palielinot mēslojuma normu līdz $60 \mathrm{~kg} \mathrm{ha}^{-1} \mathrm{~N}$, arī sausnas raža turpināja būtiski palielināties. Taču tālāka slāpekḷa normas palielināšana būtiskus ražas pieaugumus nenodrošināja. Arī 3. zelmeņa izmantošanas gadā niedru auzenei būtisku sausnas ražas pieaugumu ieguva, lietojot slāpekḷa mēslojuma normas 30,120 un $180 \mathrm{~kg} \mathrm{ha}^{-1}$ N. Ceturtajā zelmeņa izmantošanas gadā būtisku $(p<0.05)$ ražas palielinājumu 
ieguva, lietojot 60,120 un $180 \mathrm{~kg} \mathrm{ha}^{-1} \mathrm{~N}$ normu, savukārt 5. zelmeņa izmantošanas gadā būtisks ražas palielinājums tika iegūts ar slāpekḷa normām 60 un $120 \mathrm{~kg} \mathrm{ha}^{-1} \mathrm{~N}$.

Niedru auzenei 1. zelmeņa izmantošanas gadā, lai pārsniegtu $8.0 \mathrm{t} \mathrm{ha}^{-1}$ sausnas ražu, no agronomiskā viedokḷa raugoties, jālieto augstas slāpekḷa normas $\left(>150 \mathrm{~kg} \mathrm{ha}^{-1} \mathrm{~N}\right)$. Šai stiebrzālei līdz ar zelmeņa vecumu, kad tas kḷūst spēcīgāks un blīvāks, jālieto $120 \mathrm{~kg} \mathrm{ha}^{-1} \mathrm{~N}$ un vairāk slāpekḷa mēslojuma, lai noturētu sausnas ražu $>8.0 \mathrm{t} \mathrm{ha}^{-1}$.

Ar polinomu lineāro sadalīšanu tika noteikts faktoru mijiedarbības efekts, t.i., kā izmantošanas gadi un fons ietekmēja slāpekḷa mēslojuma normu palielināšanas efektivitāti un līdz kādam lielumam bija lietderīgi kāpināt slāpekḷa mēslojuma normas (2. att.).

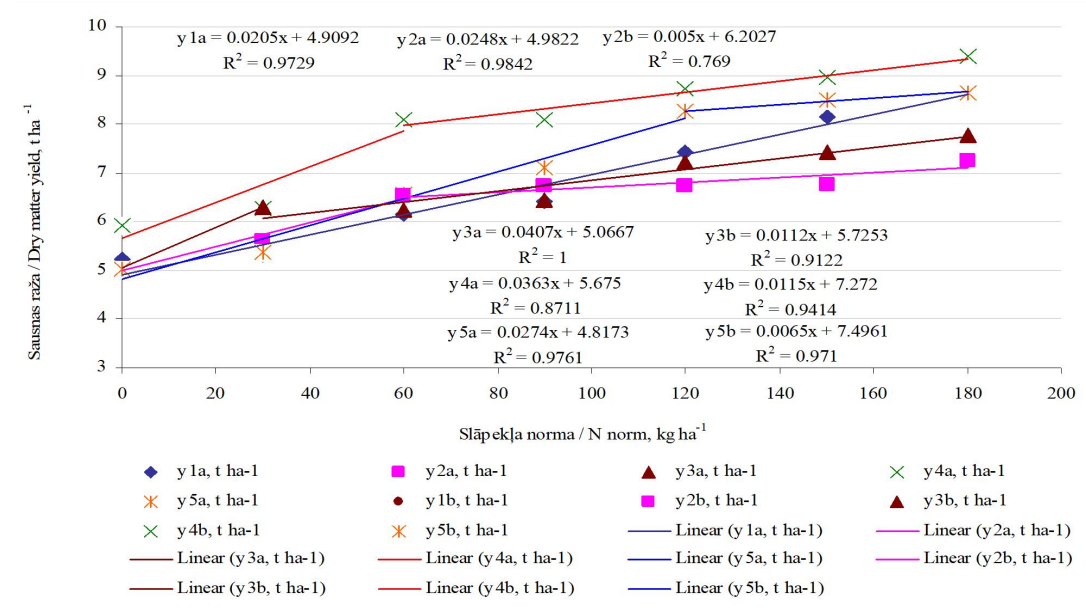

Lineāro sakarību izmainas ar regresijas koeficientiem ayx un byx definīcijas apgabalos: yla un ylb - pirmajā zelmeña izmantošanas gadā; y2a un y2b - otrajā gadā; y3a un y3b - trešajā gadā; y4a un y4b - ceturtajā gadā; y5a un y5b - piektajā izmantošanas gadā.

\section{2. att. / Fig. 2. Slāpekḷa normu palielināšanas efektivitāte niedru auzenes}

zelmen,os. / Efficiency of increasing nitrogen fertilizer norms for tall fescue sward.

Izmantojot lineāros regresijas koeficientus, konstatēja, ka niedru auzene 1. zelmeņa izmantošanas gadā augstāko slāpekḷa efektivitāti sasniedza ar slāpekḷa mēslojuma normu $180 \mathrm{~kg} \mathrm{ha}^{-1} \mathrm{~N} ; 2$. un 4. gadā - ar slāpekḷa normu $60 \mathrm{~kg} \mathrm{ha}^{-1} \mathrm{~N} ; 3$. gadā - ar slāpekḷa normu $30 \mathrm{~kg} \mathrm{ha}^{-1} \mathrm{~N} ; 5$. izmantošanas gadā ar slāpekḷa normu $120 \mathrm{~kg} \mathrm{ha}^{-1} \mathrm{~N}$. 


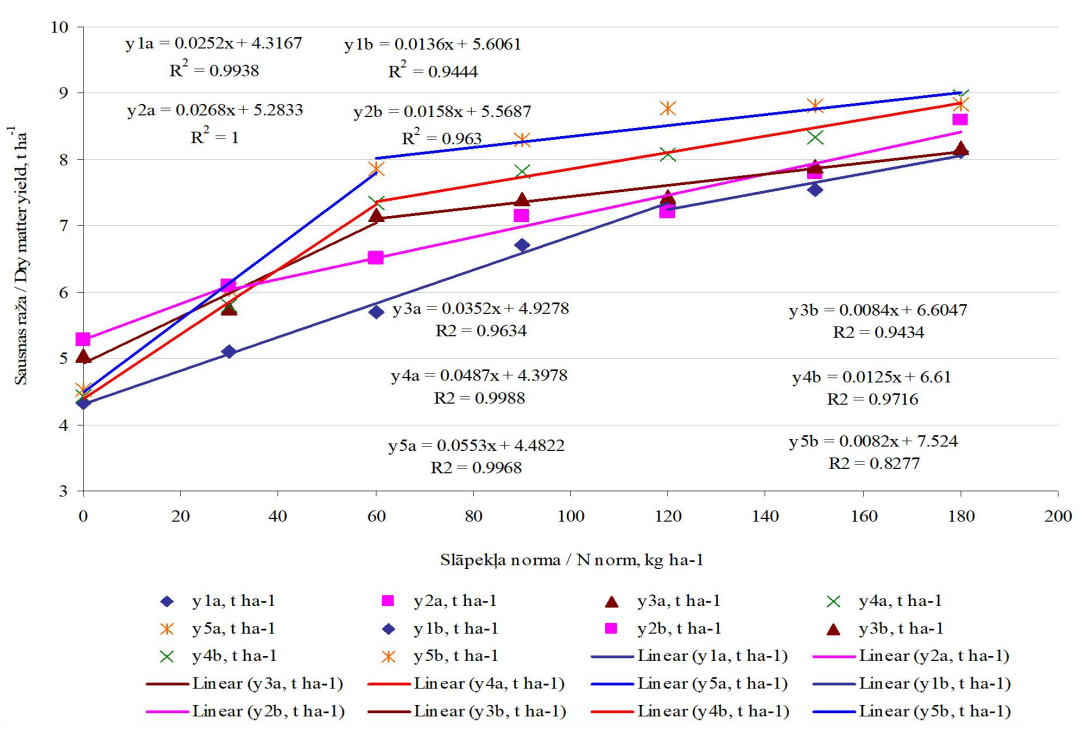

Lineāro sakarību izmainas ar regresijas koeficientiem ayx un byx definīcijas apgabalos: yla un y1b - pirmajā zelmeṇa izmantošanas gadā; y2a un y2b - otrajā gadā; y3a un y3b - trešajā gadā; y4a un y4b - ceturtajā gadā; y5a un y5b - piektajā gadā.

\section{3. att. / Fig. 3. Slāpekḷa normu palielināšanas efektivitāte auzeṇairenes}

zelmeños. / Efficiency of increasing nitrogen fertilizer norms for festulolium sward.

Lineāro koeficientu izvērtējums apstiprināja iepriekš konstatētās un aprakstītās sausnas ražas pieauguma būtiskuma svārstības. Savukārt auzeņairenei slāpekḷa normu palielināšanas augstākā efektivitāte zelmeṇa 1 . izmantošanas gadā tika sasniegta, lietojot $120 \mathrm{~kg} \mathrm{ha}^{-1} \mathrm{~N}$ normu, 2. gadā lietojot $30 \mathrm{~kg} \mathrm{ha}^{-1} \mathrm{~N}$, un no 3 . līdz 5. zelmeṇa izmantošanas gadam - lietojot $60 \mathrm{~kg} \mathrm{ha}^{-1} \mathrm{~N}$ normu.

Timotiṇam sausnas ražu būtiski $(p<0.05)$ paaugstināja slāpekḷa mēslojums (4. att.). Jau $30 \mathrm{~kg} \mathrm{ha}^{-1} \mathrm{~N}$ norma l̦āva sasniegt $5.86 \mathrm{t} \mathrm{ha}^{-1}(+18 \%)$ sausnas ražu vidēji trīs gados. Slāpekḷa mēslojuma norma $180 \mathrm{~kg} \mathrm{ha}^{-1} \mathrm{~N}$ fosfora un kālija mēslojuma fonā vidēji trīs gadu laikā deva iespēju iegūt $8.60 \mathrm{t} \mathrm{ha}^{-1}$ sausnas ražu, kas bija 2.27 reizes vairāk nekā variantā bez mēslojuma. Visos trīs timotiņa izmantošanas gados variantā ar $180 \mathrm{~kg} \mathrm{ha}^{-1} \mathrm{~N}$ normu tika iegūti augstākie ražas pieaugumi: no $2.70 \mathrm{t} \mathrm{ha}^{-1}(+47 \%)$ līdz $4.59 \mathrm{t} \mathrm{ha}^{-1}(+118 \%)$.

Pḷavas auzene bija atsaucīga uz slāpekḷa mēslojumu, kas l̦āva būtiski $(p<0.05)$ paaugstināt sausnas ražu. Ar katru slāpekḷa normas soli, sākot no $30 \mathrm{~kg} \mathrm{ha}^{-1} \mathrm{~N}$, sausna raža būtiski palielinājās, un augstākais rādītājs $-8.13 \mathrm{t} \mathrm{ha}^{-1}$ (vidēji trīs zelmeņa izmantošanas gados) - tika iegūts, lietojot slāpekḷa normu $180 \mathrm{~kg} \mathrm{ha}^{-1} \mathrm{~N}$ (4. att.). 


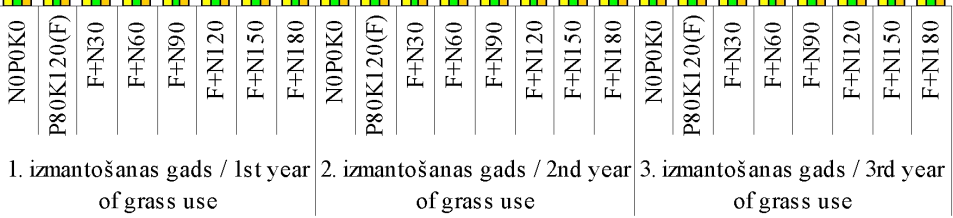

Zelmeṇa izmantošanas gads, un NPK normas, $\mathrm{kg} \mathrm{ha}^{-1}$ / Year of grass use, and NPK norms, $\mathrm{kg} \mathrm{ha}^{-1}$

$\square$ Timotinšs / Timothy $\square$ Pḷavas auzene / Meadow fescue $\square$ Miežabrālis / Reed canary gras s

4. att. / Fig. 4. Mēslojuma ietekme uz timotiṇa, pḷavas auzenes un miežabrāḷa sausnas ražu. / Effect of fertilizer on dry matter yield of timothy, meadow fescue and reed canary grass.

Miežabrāḷa sausnas ražas maksimums tika iegūts, lietojot $\leq 60 \mathrm{~kg} \mathrm{ha}^{-1} \mathrm{~N}$ mēslojuma normu visos izmantošanas gados (4. att.); tālāka normas paaugstināšana nedeva būtisku ražas pieaugumu.

Ar polinomu lineāro sadalī̌sanu, izmantojot lineāros regresijas koeficientus, konstatēja, ka timotiņam zelmeņa izmantošanas gados slāpekḷa mēslojuma augstākās efektivitātes rādītāji atšḳīrās: 1. zelmeṇa izmantošanas gadā timotiņam slāpekḷa augstākā efektivitāte tika iegūta ar slāpekḷa normu $30 \mathrm{~kg} \mathrm{ha}^{-1} \mathrm{~N}$ (5. att.), 2. gadā slāpeklis bija nepieciešams krietni vairāk $120 \mathrm{~kg} \mathrm{ha}^{-1} \mathrm{~N}$, bet 3. zelmeņa izmantošanas gadā augstākā efektivitāte tika sasniegta ar $60 \mathrm{~kg} \mathrm{ha}^{-1}$ slāpekḷa normu.

Ar polinomu lineāro sadalīšanu, izmantojot lineāros regresijas koeficientus, konstatēja, ka slāpekḷa normu palielināšanas augstākā efektivitāte plavas auzenes zelmeņa 1. un 3. izmantošanas gadā tika iegūta, lietojot $30 \mathrm{~kg} \mathrm{ha}^{-1} \mathrm{~N}$ normu (6. att.), bet 2. izmantošanas gadā - lietojot $60 \mathrm{~kg} \mathrm{ha}^{-1} \mathrm{~N}$.

$\mathrm{Ar}$ polinomu lineāro sadalī̌sanu, izmantojot lineāros regresijas koeficientus, noskaidroja, ka miežabrālim augstākā slāpekḷa mēslojuma efektivitāte tika sasniegta ar $60 \mathrm{~kg} \mathrm{ha}^{-1} \mathrm{~N}$ mēslojuma normu 1. un 2. zelmeņa izmantošanas gadā, bet 3 . gadā pietika ar $30 \mathrm{~kg} \mathrm{ha}^{-1} \mathrm{~N}$ normu (7. att.). 


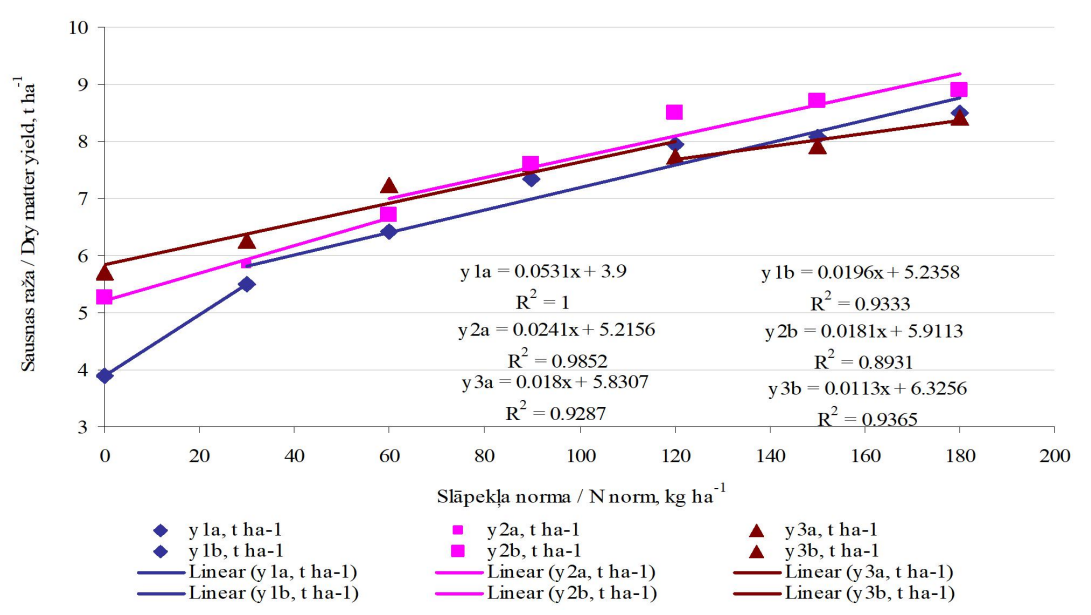

Lineāro sakarību izmainas ar regresijas koeficientiem ayx un byx definīcijas apgabalos: yla un ylb - pirmajā zelmeņa izmantošanas gadā; y2a un y2b - otrajā gadā; y3a un y3b - trešajā gadā.

\section{5. att. / Fig. 5. Slāpekḷa normu palielināšanas efektivitāte timotiṇa}

zelmenos. / Efficiency of increasing nitrogen fertilizer norms for timothy sward.

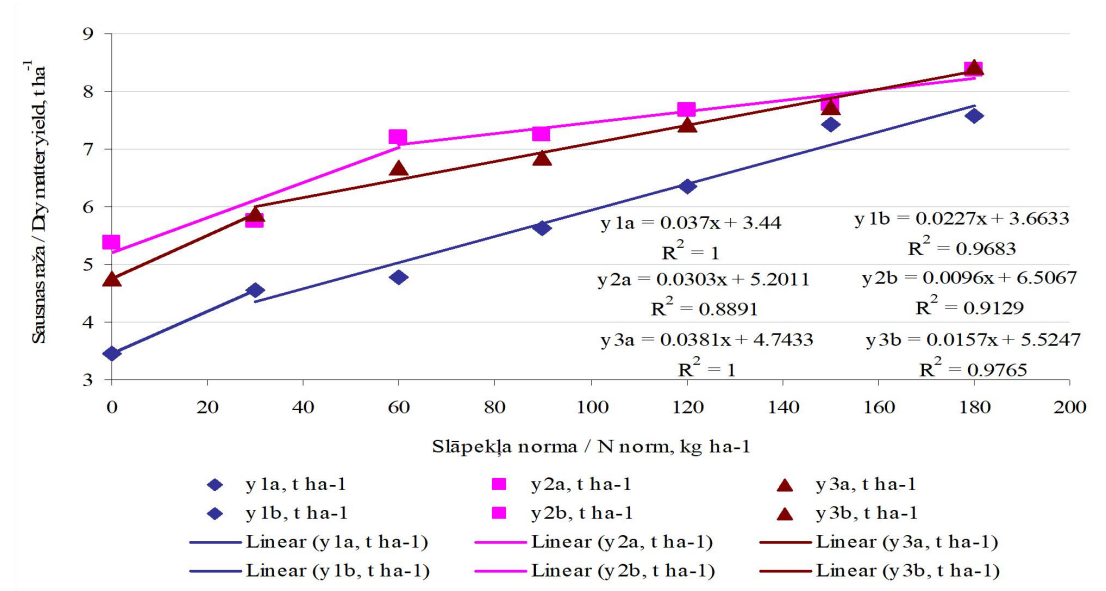

Lineāro sakarību izmaiṇas ar regresijas koeficientiem ayx un byx definīcijas apgabalos: yla un y1b - pirmajā zelmeņa izmantošanas gadā; y2a un y2b - otrajā gadā; y3a un y3b - trešajā gadā.

\section{6. att. / Fig. 6. Slāpekḷa normu palielināšanas efektivitāte pḷavas} auzenes zelmeņos. / Efficiency of increasing nitrogen fertilizer norms for meadow fescue sward. 


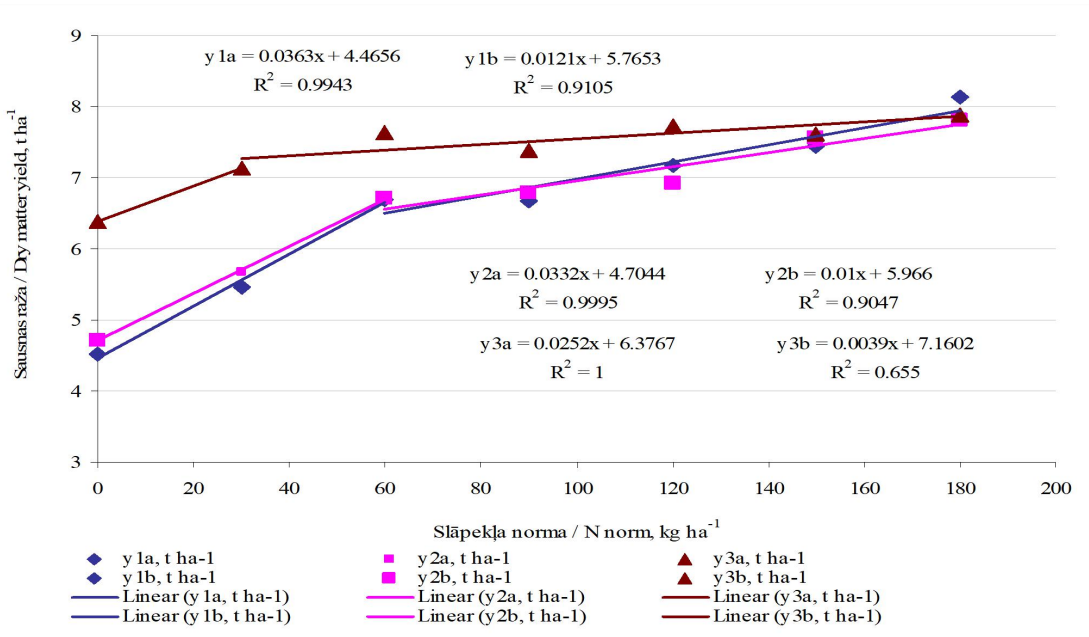

Lineāro sakarību izmainas ar regresijas koeficientiem ayx un byx definīcijas apgabalos: yla un ylb - pirmajā zelmeņa izmantošanas gadā; y2a un y2b - otrajā gadā; y3a un y3b - trešajā gadā.

\section{7. att. / Fig. 7. Slāpekḷa normu palielināšanas efektivitāte miežabrāḷa} zelmeṇos. / Efficiency of increasing nitrogen fertilizer norms for reed canary grass sward.

\section{Slāpekḷa mēslojuma izmantošanas efektivitāte stiebrzāḷ audzēšanā}

Stiebrzālēm augstākā slāpekḷa izmantošanas efektivitāte no $1 \mathrm{~kg}$ lietotā slāpekḷa tika sasniegta, lietojot mazas slāpekḷa normas - 30-60 kg ha-1 $\mathrm{N}(8$. att.).

Lietojot vidējas slāpekḷa mēslojuma normas $\left(90-120 \mathrm{~kg} \mathrm{ha}^{-1} \mathrm{~N}\right)$, gandrīz visos gadījumos iegūtais sausnas daudzums samazinājās, izṇemot timotinuu 2. izmantošanas gadā. Lielu slāpekḷa mēslojuma normu $\left(150-180 \mathrm{~kg} \mathrm{ha}^{-1} \mathrm{~N}\right)$ lietošana stabili uzrādīja sausnas ražas pieaugumu 1. zelmeņa izmantošanas gadā. Iegūtie rezultāti liecināja, ka no visām stiebrzāḷu sugām niedru auzene bija visatsaucīgākā uz slāpekḷa mēslojumu zelmeņa attīstības sākumā, kad sausnas ražas palielināšanās no $1 \mathrm{~kg}$ lietotā slāpekḷa tika sasniegta, palielinot slāpekḷa normu visos devu lieluma līmenonos.

Pirmajā zelmeņa izmantošanas gadā timotiņš slāpekli izmantoja labāk, ja tika lietotas mazas slāpekḷa mēslojuma normas, bet niedru auzenei augstāka slāpekḷa izmantošanas efektivitāte tika iegūta, lietojot lielas slāpekḷa normas. Savukārt 2. zelmeņa izmantošanas gadā abām stiebrzāḷlu sugām slāpekḷa izmantošanas efektivitāte bija proporcionāli apgrieztā pozīcijā salīdzinājumā ar 1. izmantošanas gadu. 


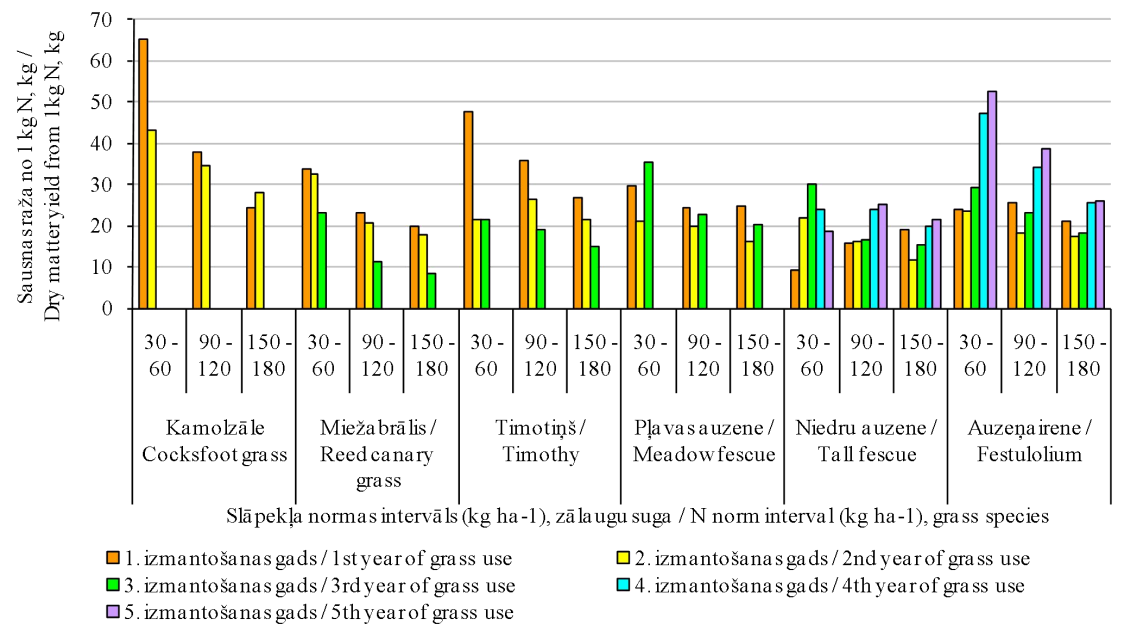

8. att. / Fig. 8. Slāpekḷa mēslojuma efektivitāte no 1 kg lietotā $\mathbf{N}$ atkarībā no mēslojuma normas. / Nitrogen fertilizer efficiency of $1 \mathrm{~kg}$ applied $N$ depending on fertilizer norm.

Miežabrālim augstākā slāpekḷa izmantošanās - vidēji 37.2\% - tika konstatēta, lietojot $60 \mathrm{~kg} \mathrm{ha}^{-1} \mathrm{~N}$ mēslojuma normu.

Timotiņam vidēji divos gados, neskatoties uz slāpekḷa izmantošanas atšķirībām atsevišķos audzēšanas gados, augstākā slāpekḷa izmantošanās sasniedza 41.7-43.1\% variantos ar slāpekḷa normu 90-120 kg ha-1 N. Pḷavas auzenei labāka slāpekḷa izmantošanās $(41.8 \%)$ vidēji divos gados tika novērota variantā ar $60 \mathrm{~kg} \mathrm{ha}^{-1} \mathrm{~N}$ normu.

\section{Stiebrzāḷu biomasas kurināmā kvalitātes rādītāju novērtēšana}

Mitruma saturs biomasā ir main̄̄gs lielums, kas ietekmē kurināmā kvalitāti un pašizmaksu. Lai samazinātu mitruma saturu, jāiegulda ievērojams enerğijas daudzums, kas kurināmā ražošanas procesā veido vienu no lielākajām izdevumu pozīcijām. Pētījumā stiebrzāḷu biomasas mitrums pirms granulēšanas vidēji bija $9.00 \%$ (no $8.10 \%$ plavas auzenei līdz $10.40 \%$ auzenairenei), bet koksnei $-7.82 \%$ (no 7.00\% kārklam līdz 8.50\% hibrīdapsei un bērzam), kas atbilda standarta prasībām. Mitruma saturs stiebrzāḷ un koksnes biomasu maisījumiem arī bija mazāks par 10\%, turklāt tas samazinājās līdz ar koksnes daudzuma palielināšanos. Pievienojot $1 / 3$ koksnes, biomasas maisījumu mitrums samazinājās vidēji par 5\%; pievienojot pusi vai $2 / 3$ koksnes, maisījumu mitrums samazinājās attiecīgi par $15 \%$ vai $20 \%$. 
Pelni veido sakušņus, kā rezultātā ātrāk aizsērējas degšanas kamera un katla konvektīvā dal̦a, un līdz ar to biežāk jāveic mehāniskā tīrǐšana. Pētījumā tika konstatēts, ka stiebrzāḷu biomasai vidējais pelnu saturs bija robežās no $6.60 \%$ timotinam līdz 8.05\% niedru auzenei, kas ir tuvu literatūrā minētajiem pelnu satura rādītājiem (Beidermann, Obernberger, 2005; Bakker, Elbersen, 2005). Vidēji visos izmēǵinājumā iekḷautajos mēslojuma variantos pelnu saturs dažādiem stiebrzāḷu biomasu veidiem bija: $8.05 \%$ niedru auzenei, $7.36 \%$ miežabrālim, $7.27 \%$ auzeņairenei, $7.14 \%$ plavas auzenei un $6.60 \%$ timotinam.

Standarta prasībās noteikts, ka miežabrāla biomasai pelnu saturs nedrīkst pārsniegt $8.0 \%$. Miežabrālim $\geq 60 \mathrm{~kg} \mathrm{ha}^{-1} \mathrm{~N}$ mēslojuma normas sekmēja pelnu satura samazināšanos zem standartā noteiktajiem $8.0 \%$ abos zelmeņa izmantošanas gados. Auzeņairenei un timotinam pelnu saturs bija mazāks par $8.0 \%$.
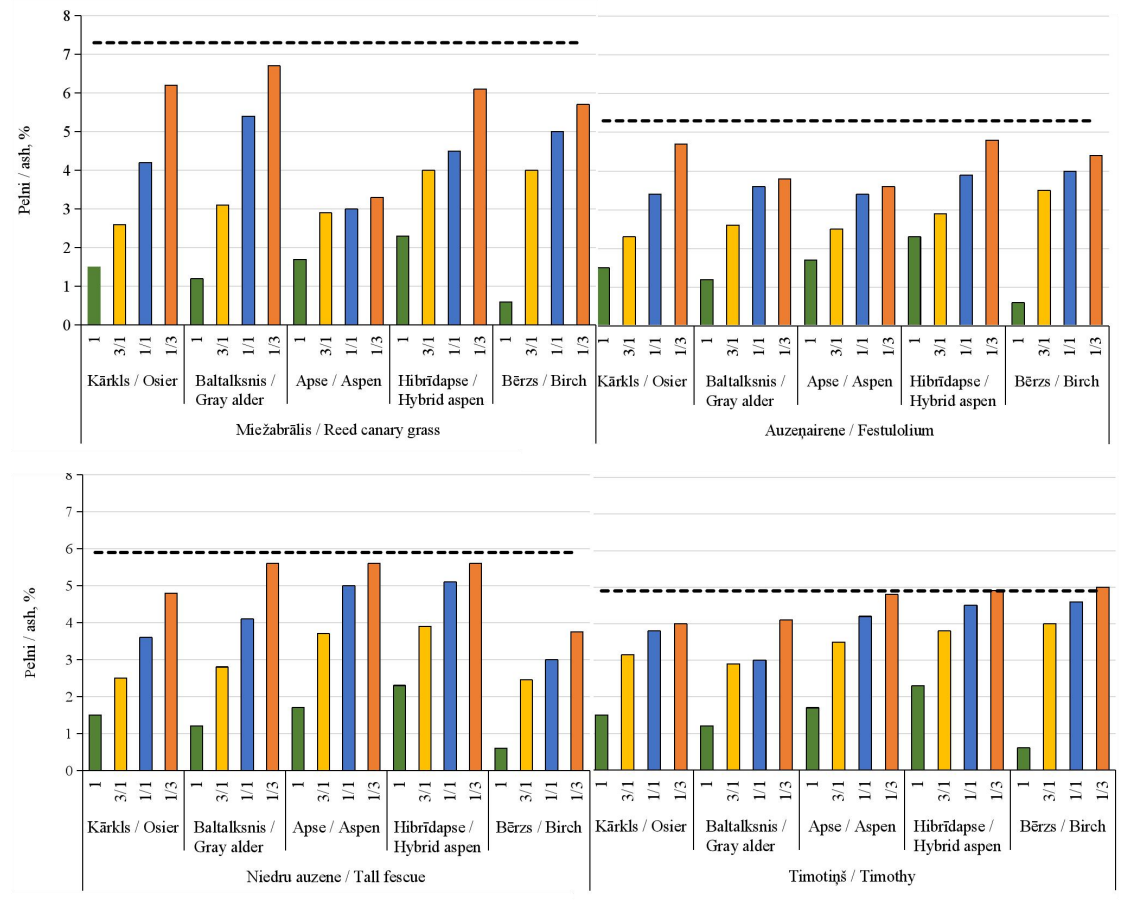

Apzīmējumi:

maisījums (koksne + stiebrzāle) / mix (timber + grass) 3/1, 1/1, 1/3; stiebrzāḷ biomasas pelnu saturs / ash content of grass biomass.

9. att. / Fig. 9. Pelnu saturs koksnes un stiebrzāḷu biomasām un to maisījumiem. / Ash content for grass and timber biomasses and their mixtures. 
Veiktā regresijas analīze liecināja, ka pelnu saturs palielinājās līdz ar kālija $\left(\mathrm{R}^{2}=0.86 ; p=0.01\right)$, fosfora $\left(\mathrm{R}^{2}=0.62 ; p=0.01\right)$, hlora $\left(\mathrm{R}^{2}=0.71\right.$; $p=0.01)$ un slāpekḷa $\left(\mathrm{R}^{2}=0.74 ; p=0.01\right)$ satura pieaugumu biomasas sausnā. To var skaidrot ar apstākli, ka šie elementi, biomasas kurināmajam sadegot, veido pelnu sastāvā ietilpstošus savienojumus (Vassilev, Vassileva, Song et al., 2017).

Stiebrzāḷu un koksnes biomasas maisījumiem pelnu saturs samazinājās proporcionāli koksnes daḷas pieaugumam, jo vidēji koksnes biomasai, salīdzinot ar stiebrzālēm, ir par 70-80\% mazāk pelnu. Stiebrzāḷu un koksnes biomasu sastāva analīze liecināja, ka stiebrzāḷ biomasai ar 1/3 koksnes piejaukuma pelnu saturs samazinājās par $20 \%$, bet, piejaucot pusi vai $2 / 3$ koksnes, pelnu saturs samazinājās attiecīgi par $40 \%$ vai $55 \%$. Zemākais pelnu satura rādītājs bija auzeņairenei un miežabrālim maisījumā $1 / 3$ ar kārklu - attiecīgi $2.30 \%$ un $2.63 \%$; niedru auzenei gan ar kārklu, gan ar bērzu - 2.5\%; timotinam ar baltalksni $-2.9 \%$ (9. att.).

Vērtējot stiebrzāḷu piemērotību kurināmā ražošanai, jāṇem vērā, ka pelnu saturs var mainīties gadu no gada, taču proporcionālās izmaiņas saglabājas. Novērojumi norāda uz pelnu satura atkarību no sugas un agrometeoroloǵiskajiem apstākḷiem.

Ogleklis (C) ir viens no ķīmiskajiem elementiem, kas nosaka no kurināmā iegūtās siltumenerǵijas daudzumu. Oglekḷa saturs augos ir svarīgs rādītājs, jo tas ir degošais elements. Jo lielāks oglekḷa saturs augos, jo augstāks sadegšanas siltums.

Oglekḷa saturs pētītajās stiebrzālēs vidēji bija no 44.5\% niedru auzenei līidz 45.3\% timotiņam. Miežabrāla sausnā C saturs vidēji bija 45.11\% (no 42.69\% 2013. gadā līdz 47.58\% 2012. gadā), savukārt variantos bez mēslojuma - vidēji 44.93\% (attiecīgi no $42.90 \%$ līdz 47.43\%).

Koksnes paraugos augstākais oglekḷa saturs bija apsei (48.90\%), bet zemākais - bērzam (46.10\%). Oglekḷa saturs stiebrzāḷu izmēginājumā 1. un 2. izmantošanas gadā variēja no $42.00 \%$ pḷavas auzenei 2013. gadā līdz 48.97\% timotinam 2012. gadā.

Apkopojot iegūtos rezultātus, redzams, ka variantos, kur slāpekḷa mēslojuma norma bija $\geq 120 \mathrm{~kg} \mathrm{ha}^{-1} \mathrm{~N}$, oglekḷa saturs vidēji bija lielāks par $45 \%$.

Augstākie oglekḷa satura rādītāji maisījumā 1/3 bija auzeņairenei ar kārklu un miežabrālim ar baltalksni - attiecīgi $46.6 \%$ un $46.9 \%$. Savukārt zemākie rādītāji bija auzeņaienei maisījumā $3 / 1$ ar hibrīdapsi un miežabrālim maisījumā 3/1 ar kārklu - attiecīgi $43.7 \%$ un $43.4 \%$.

Ūdeṇraža (H) saturs kurināmajā nosaka tā siltumspēju: jo vairāk ūdeņraža, jo lielāka augstākā siltumspēja.

Ūdenraža saturs analizētajos koksnes un stiebrzāḷ paraugos attiecīgi bija robežās no $5.48 \%$ timotinam līdz $5.93 \%$ niedru auzenei un no $6.39 \%$ baltalksnim līdz $6.83 \%$ bērzam. Üdeņraža saturs pētītajām stiebrzāḷu sugām vidēji bija par $6 \%$ mazāks nekā koksnes biomasas paraugos. Kopumā ūdeņraža 
saturs pētītajās biomasās bija līdzīgs. Stiebrzālēs H satura izmaiṇas bija 10\% robežās. Ūdeņraža saturs vidēji augstāks bija koksnes biomasā.

Dažu stiebrzāḷlu, tādu kā auzeñairenes, miežabrāḷa un niedru auzenes, biomasas H/C attiecība (1.51-1.52) bija līdzīga apses, hibrīdapses un baltalkšņa biomasas $\mathrm{H} / \mathrm{C}$ attiecībai (1.52). Visaugstākais rādītājs bija kārklam un bērzam 1.54. Apses maisījumos ar stiebrzālēm $\mathrm{H} / \mathrm{C}$ palielinājās līdz ar koksnes daudzuma palielināšanos, taču tas bija tikai $0.5-2 \%$.

Ūdeņraža un oglekḷa saturs norāda uz kurināmā energoietilpību, ko raksturo šo elementu atomārā attiecība H/C. Jo vairāk ūdeņraža attiecībā pret oglekli, jo zemāka oksidēšanās pakāpe un jo vairāk energijijas izdalās oksidēšanās reakcijā. Tātad - jo augstāka atomārā H/C attiecība, jo vairāk enerğijas izdalīsies, kurināmajam sadegot. Lignocelulozes biomasai H/C attiecība vidēji bija 1.5 (Lehmann, Joseph, 2009). Šajā pētījumā no stiebrzālēm visaugstākā $\mathrm{H} / \mathrm{C}$ attiecība - 1.52 - bija niedru auzenei, bet viszemākā - 1.45 plavas timotinam. No koksnes biomasām visaugstākā $\mathrm{H} / \mathrm{C}$ attiecība bija bērzam - 1.54. Kopumā pētītajām biomasām H/C attiecība krasi neatšḳīrās, un vidējā $\mathrm{H} / \mathrm{C}$ attiecība stiebrzālēm bija par $2.3 \%$ zemāka nekā koksnēm.

Slāpeklis (N), sadegot kurināmajam, veido gaistošus slāpekḷa savienojumus, kas ar neattīrìtām dūmgāzēm nonāk atmosfērā, tādēl augu biomasā kā kurināmajā tam nevajadzētu pārsniegt $0.6 \%$ robežu (Obernberger, Brunner, Barnthaler, 2006). Savukārt standartā LVS EN 14961-2-2012 (LVS EN ISO 17225-6:2014) noteikts, ka slāpekḷa saturs sausnā nedrīkst pārsniegt $2.0 \%$.

Stiebrzālēm slāpekḷa saturs atkarībā no sugas un gada bija robežās no $0.63 \%$ pḷavas auzenei 2012. gadā līdz 2.59\% pḷavas auzenei 2013. gadā. Vidēji visos izmēginājumā ierīkotajos mēslojuma variantos slāpekḷa saturs pḷavas auzenei bija $1.71 \%$, timotiņam $-1.32 \%$, auzeņairenei $-1.18 \%$, miežabrālim $1.13 \%$, niedru auzenei $-1.05 \%$.

Slāpekḷa saturs koksnes paraugos variēja no $0.3 \%$ līdz $0.6 \%$, bet miežabrālim un auzeņairenei tas attiecīgi bija $1.3 \%$ un $1.1 \%$.

Koksnes un stiebrzāḷu maisījumos slāpekḷa saturs palielinājās, palielinoties stiebrzāḷu proporcijai tajā. Maisījumu proporcijā 3/1 (75\% koksne + 25\% stiebrzāles) slāpekḷa saturs palielinājās vidēji par $23 \%$, bet proporcijās $1 / 1$ (50\% koksne $+50 \%$ stiebrzāles) un $1 / 3$ (25\% koksne $+75 \%$ stiebrzāles) attiecīgi par $36 \%$ un $56 \%$.

Fosfors (P), līdzīgi kālijam, biomasai sadegot, veido vienkāršus sāḷus, kas ietilpst pelnu sastāvā.

Fosfora saturs atkarībā no gada un stiebrzāḷu sugas bija robežās no $0.20 \%$ timotinam un plavas auzenei 2012. gadā līdz $0.47 \%$ pḷavas auzenei 2013. gadā. Vidēji visos izmēgeinājumā ierīkotajos mēslojuma variantos fosfora saturs plavas auzenei bija $0.34 \%$, miežabrālim un auzeṇairenei $-0.28 \%$, niedru auzenei $-0.27 \%$, timotinam - 0.26\%. Savukārt vidēji visos slāpekḷa minerālmēslu variantos fosfora saturs stiebrzāḷu biomasā bija: $0.35 \%(+9 \%$, 
salīdzinot ar variantu bez slāpekḷa mēslojuma) plavas auzenei, $0.28 \%(+17 \%)$ auzeņairenei, $0.28 \%(-3 \%)$ miežabrālim, $0.26 \%$ (attiecīgi $-7 \%$ un $-10 \%$ ) timotinam un niedru auzenei.

Kālija (K) saturs ir būtisks biomasas kvalitātes rādītājs, jo sārmu metāli (kālijs un nātrijs) samazina pelnu kušanas temperatūru, kas savukārt izraisa izdedžu slān̨a veidošanos uz sadedzināšanas iekārtu sienām.

Stiebrzālēm kālija saturs atkarībā no sugas un gada bija robežās no $1.37 \%$ pḷavas auzenei 2012. gadā līdz 3.69\% pḷavas auzenei 2013. gadā. Vidēji visos izmēǵinājumā ierīkotajos mēslojuma variantos kālija saturs pḷavas auzenei bija $2.69 \%$, auzeņairenei $-2.61 \%$, timotinam $-2.52 \%$, niedru auzenei $-2.45 \%$, miežabrālim $-2.21 \%$.

Korelācijas analīze liecināja, ka pastāvēja vāja pozitīva saistība starp K saturu augos un mēslojuma normu $(\mathrm{r}=0.31 ; p=0.1)$.

Vidēji visos slāpekḷa minerālmēslu variantos stiebrzāḷu biomasā kālija saturs bija: $2.70 \%$ pḷavas auzenei, $2.66 \%$ auzeņairenei, $2.55 \%$ timotinam, $2.50 \%$ niedru auzenei un $2.33 \%$ miežabrālim.

Kālija saturu vairāk ietekmēja konkrētā gada meteorologiskie apstākḷi. Nokrišņiem bagātajā 2012. gadā stiebrzāḷu intensīvas veǵetācijas periodā kālija saturs stiebrzāḷ biomasā atkarībā no sugas variēja no $1.37 \%$ pḷavas auzenei līdz 2.31\% niedru auzenei, bet sausajā 2013. gadā - no $1.95 \%$ miežabrālim līdz $3.69 \%$ plavas auzenei. Tas tikai apstiprina citu pētnieku domu, ka palielināts augsnes mitrums samazina kālija uzkrāšanās procesu augos (Nutalapati, Gupta, Moghtaderi et al., 2007).

Sērs (S) ir viens no nevēlamiem elementiem, jo izraisa kurināšanas iekārtu koroziju. Sēra saturs augos, tajā skaitā stiebrzālēs, ir ḷoti mainīgs.

Šajā pētījumā sēra saturs stiebrzāḷ biomasā bija robežās no $0.036 \%$ timotinam 2012. gadā līdz $0.180 \%$ timotinam 2013. gadā. Sēra saturs analizētajos stiebrzālu sugu paraugos vidēji bija $0.013 \%$, bet koksnei - vidēji $0.029 \%$, un šīs vērtības nepārsniedza standartos noteiktos rādītājus. Koksnes un stiebrzāḷu maisījumos sēra saturs salīdzinājumā ar tīras koksnes biomasas paraugiem vidēji palielinājās par $37 \%$ proporcijai $3 / 1$, par $39 \%$ proporcijai $1 / 1$ un par $53 \%$ proporcijai $1 / 3$.

Hlors (Cl), līdzīgi sēram, izraisa iekārtu koroziju (Rosendahl, 2013).

Hlora saturs koksnes un stiebrzāḷ biomasas paraugos bija attiecīgi 0.008 $0.012 \%$ un $0.50-0.74 \%$. Hlora saturs stiebrzālu biomasā bija $2.5-3.5$ reizes augstāks par standartā LVS EN 14961-6-2012 piel̦aujamo 0.2\% robežu. Savukārt koksnes biomasu paraugos hlora saturs bija 1.5-2.5 reizes zemāks par standartā LVS EN 14961-2-2011 noteikto 0.02\% robežu. Pētījumu rezultāti liecināja, ka hlora saturs stiebrzālēs ir ievērojami augstāks nekā koksnē. Stiebrzālu biomasā hlora saturs bija no $0.50 \%$ auzenairenei līdz $0.74 \%$ miežabrālim. Koksnes biomasas paraugos viszemākais hlora saturs tika konstatēts apsei $(0.008 \%)$, bet visaugstākais - kārklam un bērzam $(0.012 \%)$. Stiebrzāḷu un koksnes maisījumos hlora saturs samazinājās, palielinoties 
koksnes daudzumam, jo $\mathrm{Cl}$ satura ziņā koksnes un stiebrzāḷu biomasas atšķ̄īās vairāk nekā 10 reizes. Zemākie hlora satura rādītāji tika konstatēti maisījuma proporcijai 1/3: auzeņairenei ar bērzu $-0.18 \%$; miežabrālim ar hibrīdapsi $0.25 \%$; niedru auzenei ar baltalksni un timotinam ar baltalksni - attiecīgi $0.22 \%$ un $0.17 \%$.

Pēc hlora satura viszemākais izdedžu veidošanās potenciāls ir koksnes biomasai, jo $\mathrm{Cl}$ saturs tajā ir zemāks. Analizētajos maisījumos zemākās vidējās $\mathrm{Cl}$ satura vērtības bija auzeņairenei un miežabrālim.

\section{Biomasas kurināmā sadegšanas parametri}

No kurināmā iegūto siltumenerǵiju raksturo augstākās siltumspējas $\left(\mathbf{Q}_{\mathbf{a}}\right)$ rādītājs.

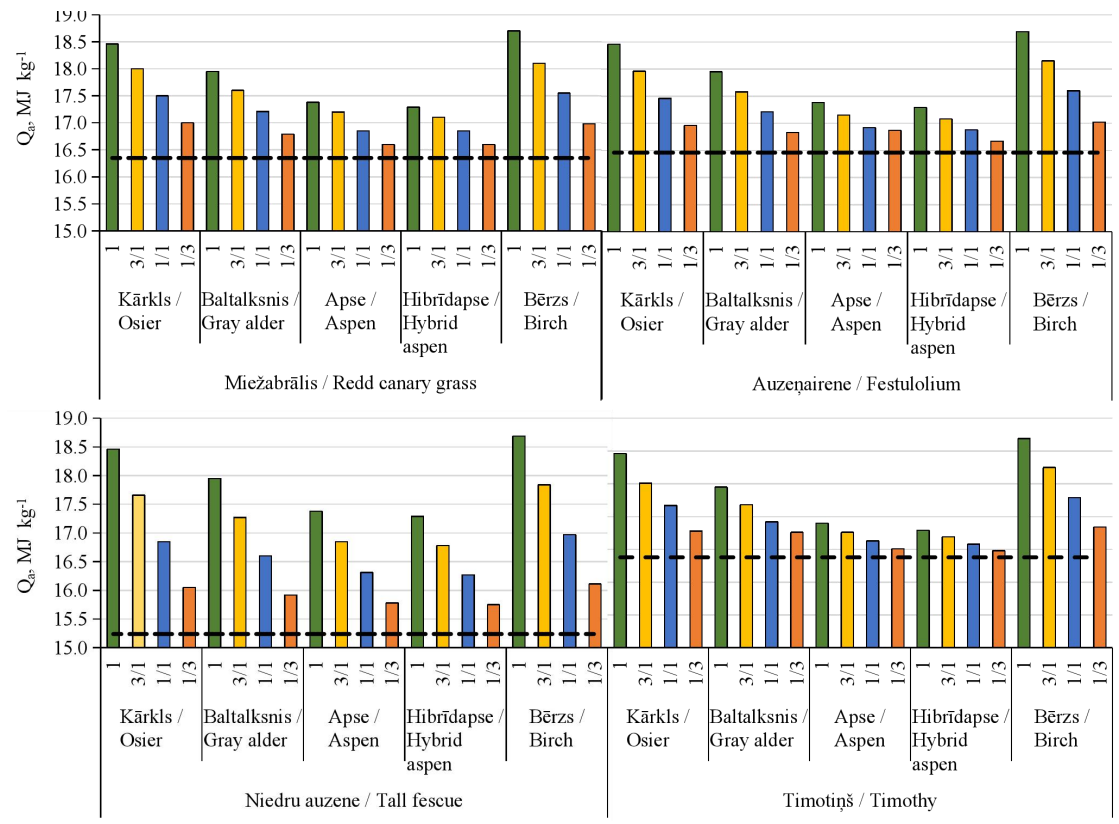

Apzīmējumi:

maisījums (koksne + stiebrzāle) / mixture (timber + grass) 3/1, 1/1,1/3, stiebrzāḷu biomasas pelnu saturs / ash content of grass biomass.

10. att. / Fig. 10. Augstākā siltumspēja koksnes un stiebrzāḷu biomasām un to maisijumiem. / Gross calorific value of grass and timber biomasses and their mixtures. 
Stiebrzāḷ biomasai lielākā $\mathrm{Q}_{\mathrm{a}}$ vērtība tika konstatēta timotinam 16.9 MJ kg-1, kas ir par 1.2-2.3\% mazāk nekā hibrīdapsei, kurai no visām pêtījumā iekḷautajām koksnēm bija zemākais augstākās siltumspējas rādītājs, vai par 9.6\% mazāk nekā bērzam, kuram bija augstākā $\mathrm{Q}_{a}$ vērtība. Savukārt zemākā $Q_{a}$ vērtība bija niedru auzenei - 15.2 $\mathrm{MJ} \mathrm{kg}^{-1}$, kas bija par 11.1-12.6\% mazāk nekā hibrīdapsei un par 18.7\% mazāk nekā bērzam. Koksnes un stiebrzāḷ biomasas maisījumos augstākā siltumspēja palielinājās, palielinoties koksnes proporcijai maisījumā (10. att.). Augstākās siltumspējas vērtības maisījuma attiecībai $1 / 3$ (25\% koksne $+75 \%$ stiebrzāles) bija no $15.8 \mathrm{MJ} \mathrm{kg}^{-1}$ niedru auzenes maisījumam ar apsi un hibrīdapsi līdz $17.3 \mathrm{MJ} \mathrm{kg}^{-1}$ timotiṇa maisījumam ar kārklu, baltalksni un bērzu, bet maisījuma attiecībai 3/1 (75\% koksne $+25 \%$ stiebrzāles) augstākās siltumspējas vērtības bija no $16.8 \mathrm{MJ} \mathrm{kg}^{-1}$ niedru auzenes maisījumam ar hibrīdapsi līdz $18.3 \mathrm{MJ} \mathrm{kg}^{-1}$ timotina maisījumam ar bērzu.

Korelācijas analīzē tika konstatēta nozīmīga $(p=0.01)$ negatīva augstākās siltumspējas korelācija ar pelnu saturu $\left(\mathrm{R}^{2}=0.45\right)$ un $\mathrm{Cl}\left(\mathrm{R}^{2}=0.47\right)$, bet korelācija ar lignīnu bija pozitīva $\left(\mathrm{R}^{2}=0.46\right)$.

Pelnu kušanas temperatūru raksturo četras fāzes: deformācijas sākuma temperatūra (DT), kušanas sākums (ST), hemisfēras punkts (HT) un plūšanas temperatūra (FT), kad izkusušie pelni izplūst pa virsmu. Starp stiebrzāḷu sugām augstākā DT bija miežabrālim $-1245^{\circ} \mathrm{C}$; pārējām stiebrzālēm tā bija robežās no $1020{ }^{\circ} \mathrm{C}$ līdz $1120{ }^{\circ} \mathrm{C}$. Koksnes biomasai DT bija robežās no $1390{ }^{\circ} \mathrm{C}$ līdz $1460{ }^{\circ} \mathrm{C}$. Tika izvērtēta koksnes un stiebrzāl̨u maisījumu deformācijas sākuma temperatūru starpība koksnes un koksnes-stiebrzāḷu maisījumu biomasām. Konstatēts, ka miežabrāḷa pievienošana koksnes biomasai samazināja biomasas maisījuma DT vidēji tikai par 14\%. Timotina, auzeņairenes un niedru auzenes pievienošana koksnei samazināja iegūtā maisījuma DT attiecīgi par 26\%, 28\% un 39\%. Korelācijas analīze nenorādīja uz saikni starp pelnu kušanas temperatūru un citiem noteiktajiem parametriem.

Pētnieki dažādās pelnu kušanas temperatūru atškirības skaidro ar stiebrzāḷu kị̄misko sastāvu, kas augstas temperatūras ietekmē var izraisīt zināmas ḳimiskas reakcijas pat vienas sugas ietvaros (Kaḳītis, Šmits, Belicka, 2009). Konstatēts, ka, palielinoties kālija oksīda saturam, samazinās arī pelnu kušanas temperatūra (Kalnačs, Grehovs, Grigale u.c., 2008).

\section{Biomasas kurināmā izejvielu enerğētiskā vērtība}

Pētītajām stiebrzāḷu sugām iegūtais enerǵijas daudzums bija tieši atkarīgs no stiebrzāḷu ražības. Vislielākais enerğijas daudzums no visām stiebrzāḷu biomasām 2012.-2013. gadā tika iegūts: no $120.7 \mathrm{GJ} \mathrm{ha}^{-1}$ niedru auzenei līdz $146.8 \mathrm{GJ} \mathrm{ha}^{-1}$ timotinam variantā $\mathrm{F}+\mathrm{N} 180$. Nelietojot mēslojumu, iegūtais enerğijas daudzums dažādām stiebrzāḷu sugām variēja no $49.0 \mathrm{GJ} \mathrm{ha}^{-1}$ pḷavas auzenei līdz 67.2 GJ ha ${ }^{-1}$ miežabrālim. Fosfora un kālija mēslojuma variantā 
iegūtais enerǵijas daudzums bija robežās no $69.3 \mathrm{GJ}^{-1} \mathrm{~h}^{-1}$ pḷavas auzenei $(+41 \%$, salīdzinot ar kontroles variantu) līdz $79.3 \mathrm{GJ} \mathrm{ha}^{-1}(+19 \%)$ auzeņairenei.

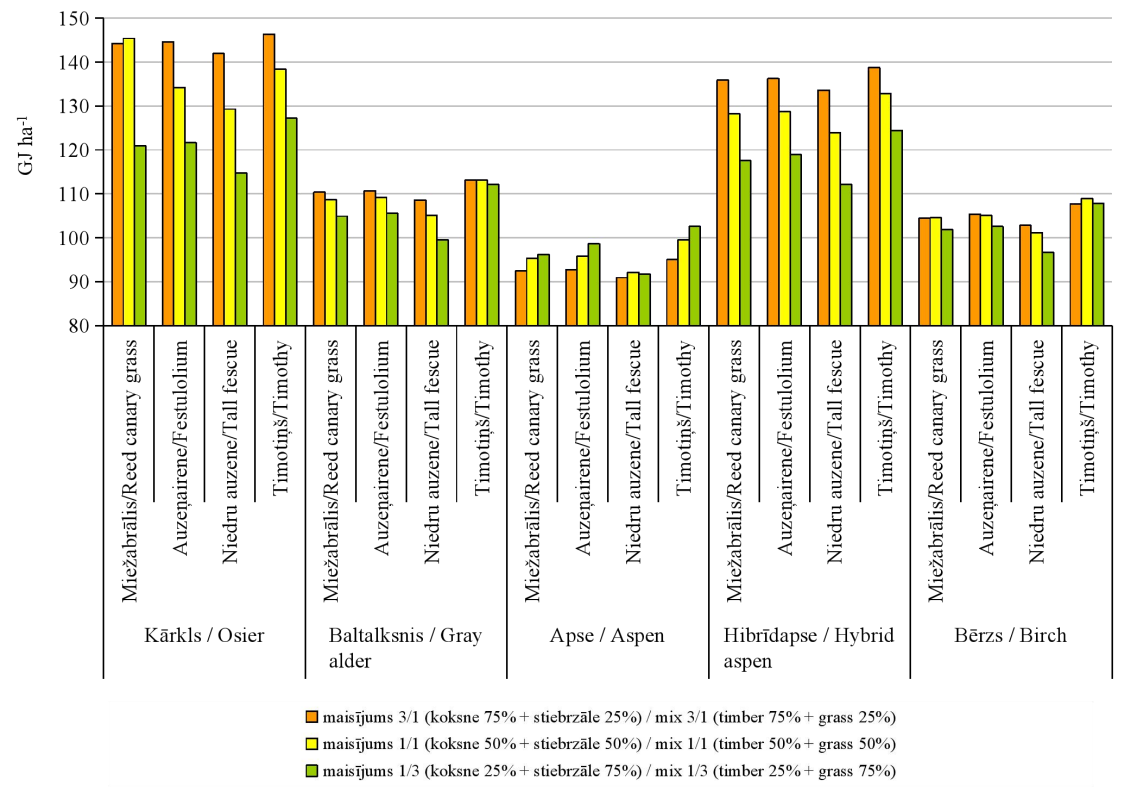

Koksnes un stiebrzāḷ biomasas / Timber and grass biomass

\section{1. att. / Fig. 11. Iegūtā enerğijas raža no koksnes un stiebrzāḷu biomasu} maisījumiem. / Energy yield from grass and timber biomass mixtures.

Slāpekḷa mēslojums sekmēja ne tikai sausnas ražas pieaugumu, bet arī iegūto energíjas daudzumu. Vidēji visos slāpekḷa normu variantos iegūtais enerğijas daudzums bija no $103.5 \mathrm{GJ} \mathrm{ha}^{-1}$ niedru auzenei līdz $126.8 \mathrm{GJ} \mathrm{ha}^{-1}$ timotiņam, ar attiecīgu iegūtās enerğijas pieaugumu no 33\% līdz 64\%. Vidēji 2012.-2013. gadā visvairāk enerğijas (11. att.) tika saražots, maisot kārklu (visaugstākā produktivitāte no pêtījumā izmantotajām koksnēm) ar katru no stiebrzālu sugām attiecību proporcijā 3/1 (75\% koksne $+25 \%$ stiebrzāles), t.i., ar koksnes pārsvaru, kas ḷāva pārsniegt $140 \mathrm{GJ} \mathrm{ha}^{-1}$ : no $141.9 \mathrm{GJ}$ ha ${ }^{-1}$ maisījumā ar niedru auzeni līdz $146.4 \mathrm{GJ}^{-1}$ maisījumā ar timotinu. Samazinoties koksnes īpatsvaram biomasu maisījumā, attiecīgi samazinājās ne tikai tā augstākā siltumspēja, bet arī saražotais enerğijas daudzums. 


\section{Biomasas kurināmā izejvielu ražošanas izmaksas}

Šajā promocijas darbā pētīto zālaugu audzēěanas agrotehniskie paṇēmieni bija vienādi un salīdzināmi, lai novērtētu to ietekmi uz zālaugu produktivitāti un konstatētu atškirīību nianses atškirīgos mēslojuma variantos. Savukārt koksnes biomasas ieguves izmaksas tika iegūtas, pamatojoties uz literatūrā atrodamajām norādēm.

Salīdzinošs apkopojums par vidējām stiebrzāḷu un koksnes biomasu iegūšanas izmaksām parādīts 12. attēlā. Kā rāda aprēḳinu rezultāti, vidēji gadā vismazāk izdevumu - 122.82 EUR ha ${ }^{-1}$ - stiebrzāḷ biomasas ieguvē bija variantā, kad netika lietots mēslojums (ņemot vērā izmantošanas ilgumu - 10 gadus), kas ir saistīts ar zelmeņa atjaunošanās biežumu. Fona (P80K120) mēslojuma variantā izdevumi veidoja $347.82 \mathrm{EUR} \mathrm{ha}^{-1}$, bet fona variantā ar slāpekḷa mēslojumu - no $394.22 \mathrm{EUR} \mathrm{ha}^{-1}$ (ar slāpekḷa normu $30 \mathrm{~kg} \mathrm{ha}^{-1} \mathrm{~N}$ ) līdz 551.20 EUR ha $^{-1}$ (ar slāpekḷa normu $180 \mathrm{~kg} \mathrm{ha}^{-1} \mathrm{~N}$ ). Stiebrzāl̨u audzēšanas agrotehnikā mēslojums ne tikai nodrošina sausnas ražas pieaugumu, bet rada arī papildu izdevumus, kas sadārdzina produkcijas pašizmaksu.

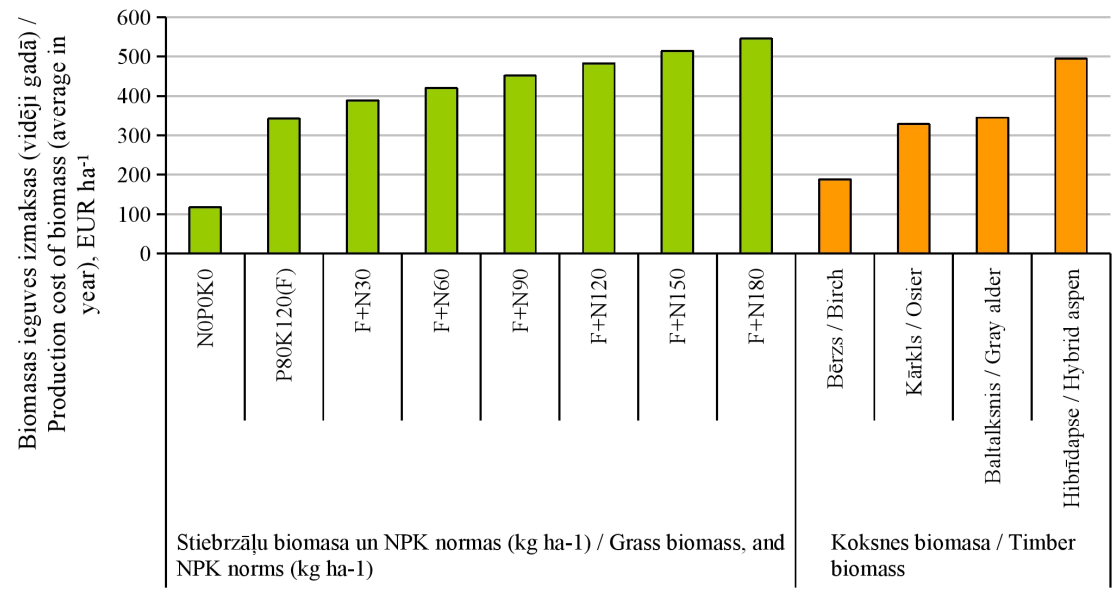

12. att. / Fig. 12. Vidējās viena gada izmaksas (EUR ha'-1) stiebrzāḷu biomasas (lietojot atšḳirīgas mēslojuma normas) un koksnes biomasas ražošanai. / Average annual costs (EUR $\left.h a^{-1}\right)$ for the production of timber biomass and the biomass of grasses applying different fertilizer norms.

Lai novērtētu koksnes pašizmaksu promocijas darba vajadzībām, katram koksnes veidam tika izmantotas izmaksu augstākās vērtības, kuras attiecināja uz doto koksnes ražošanas aprites ciklu (kārklam, hibrīdapsei un baltalksnim 20 gadi; bērzam - 40 gadi) kā vidējās vērtības uz vienu gadu, lai varētu tās 
salīdzināt ar stiebrzāl̨u ražošanas izmaksām, jo stiebrzāḷ sausnas ražu iegūst katru gadu, bet koksni - tikai periodiski. Baltalkšņa apsaimniekošanas izdevumus aprēḳināja kā vidējo vērtību no kārkla, bērza un hibrīdapses maksimālajām vērtībām. Balstoties uz šo pienēēmumu, kopējās izmaksas aprites ciklā enerğētiskās koksnes biomasas ieguvei kārklam bija 6574.75 EUR ha $^{-1}$ (vidēji gadā 328.74 EUR ha ${ }^{-1}$ ), bērzam - 7515.70 EUR ha-1 (vidēji gadā 187.89 EUR ha-1), hibrīdapsei - 9891.50 EUR ha $^{-1}$ (vidēji gadā 494.58 EUR ha ${ }^{-1}$ ), baltalksnim - 6899.43 EUR ha-1 (vidēji gadā 344.97 EUR ha ${ }^{-1}$ ). Aprēḳini liecina, ka analizētajām stiebrzāḷu un koksnes biomasām bija zema enerğijas pašizmaksa $\left(\leq 0.8\right.$ eirocenti $\left.\mathrm{kWh}^{-1}\right)$. No analizētajām koksnēm augstākā enerğijas pašizmaksa bija hibrīdapsei, bet zemākā - bērzam: attiecīgi 0.8 un 0.28 eirocenti $\mathrm{kWh}^{-1}$. Savukārt stiebrzāḷu sugām enerǵijas pašizmaksas bija līdzīgas: no 0.69 līdz 0.74 eirocentiem $\mathrm{kWh}^{-1}$ (13. att.).

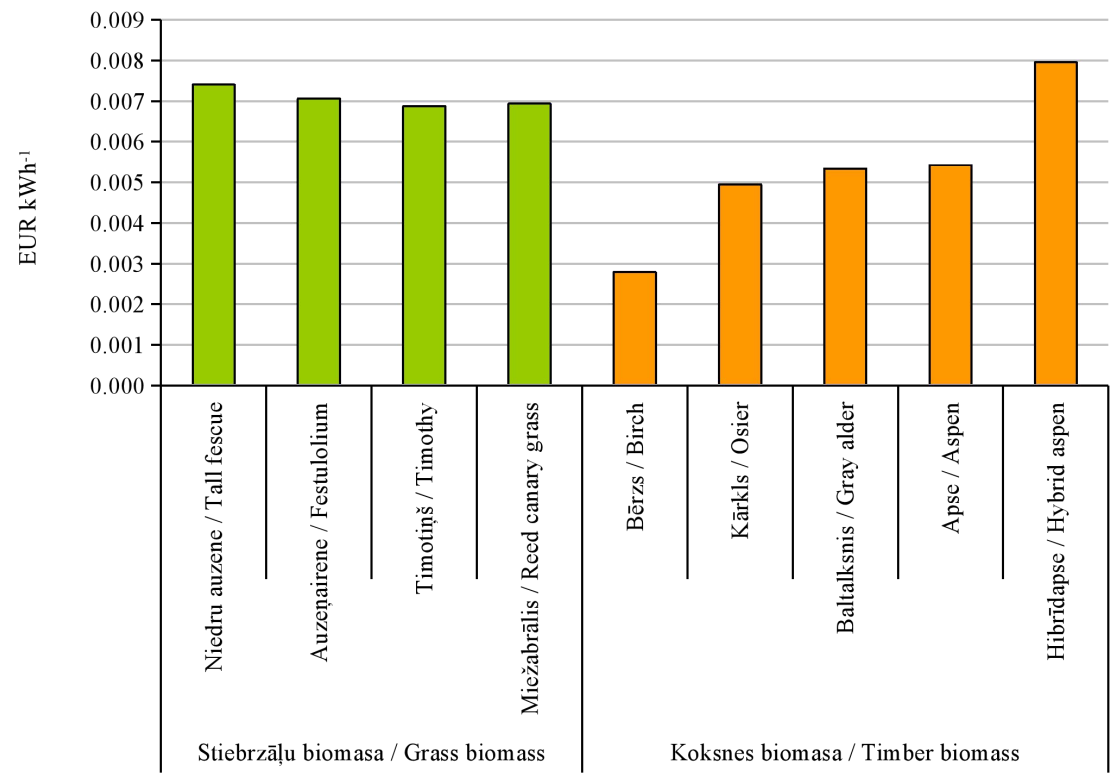

13. att. / Fig. 13. Iegūtās enerğijas pašizmaksa stiebrzāḷu un koksnes

biomasām. / The cost price of resulting energy for grass and timber biomasses.

Augstākā enerğijas pašizmaksa tika konstatēta variantos, kad stiebrzāḷu audzēšanā izmantoja fosfora un kālija minerālmēslus, proti, $80 \mathrm{~kg} \mathrm{ha}^{-1} \mathrm{P}_{2} \mathrm{O}_{5}$ un $120 \mathrm{~kg} \mathrm{ha}^{-1} \mathrm{~K}_{2} \mathrm{O}$ palielināja biomasas enerğijas pašizmaksu vidēji 2.27 reizes (no 1.96 reizēm plavas auzenei līdz 2.59 reizēm miežabrālim), salīdzinot ar kontroles variantu. Fosfora un kālija mēslojumu papildinot ar slāpekli, no stiebrzāḷu biomasas iegūtās enerǵijas pašizmaksa samazinājās. Lielākais 
enerǵijas pašizmaksas samazinājums (20\%) bija timotinam, sākot ar $90 \mathrm{~kg} \mathrm{ha}^{-1}$ N normu, salīdzinājumā ar variantu bez slāpekḷa mēslojuma lietošanas. Savukārt niedru auzenei neatkarīgi no lietotās slāpekḷa normas iegūtās energijjas pašizmaksas bija līdzīgas: $0.12-0.13$ eirocenti par kWh.

Veidojot koksnes un stiebrzāḷu biomasu maisījumus, zemākā enerğijas pašizmaksa bija kārkla un bērza koksnes maisījumiem ar stiebrzālēm: 0.060.10 eirocenti par kWh (14. att.). No baltalkšņa un stiebrzāl̨u maisījumiem iegūtās enerğijas pašizmaksa bija robežās no 0.09 līdz 0.10 eirocentiem par $\mathrm{kWh}$, no hibrīdapses maisījumiem ar stiebrzālēm - ap 0.10 eirocenti par kWh, un no apses maisījumiem ar stiebrzālēm - 0.11-0.12 eirocenti par $\mathrm{kWh}$.

Apkopojot zālaugu augstākās siltumspējas $\left(Q_{a}\right)$ un enerǵijas pašizmaksas rezultātus, tika konstatēta šāda tendence: jo augstāka siltumspēja, jo lētāka enerğija (15. att.).

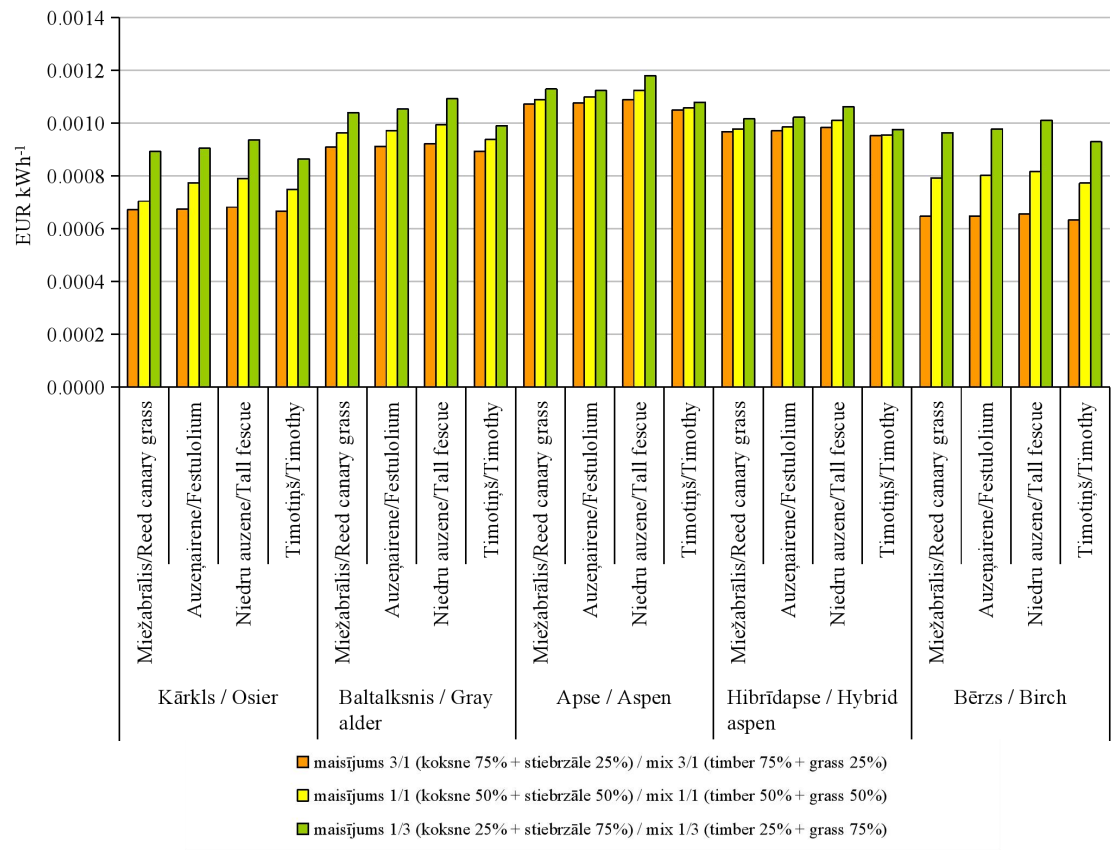

14. att. / Fig. 14. Iegūtā enerğijas pašizmaksa koksnes biomasas maisījumiem ar stiebrzālēm (vidēji 2012.-2013. g.). / The cost price of resulting energy for timber biomass mixtures with grasses (average in 2012-2013).

Salīdzinot visas pētītās stiebrzāḷu sugas, zemākā enerǵijas pašizmaksa un lielākais augstākās siltumenerğijas rādītājs bija timotinam: attiecīgi 
3.68 EUR GJ ${ }^{-1}$ un $16.88 \mathrm{MJ} \mathrm{kg}^{-1}$. Liels augstākās siltumspējas rādītājs bija arī auzeņairenei - $16.46 \mathrm{MJ} \mathrm{kg}^{-1}$, kas bija līdzīgs miežabrāḷa augstākai siltumspējai - $16.36 \mathrm{MJ} \mathrm{kg}^{-1}$; līdz ar to arī iegūtās enerǵijas pašizmaksas bija līdzīgas: attiecīgi 3.91 un 3.87 EUR GJ ${ }^{-1}$. Viszemākā augstākā siltumspēja tika konstatēta niedru auzenes un pḷavas auzenes biomasai - attiecīgi 15.24 un $15.71 \mathrm{MJ} \mathrm{kg}^{-1}$, savukārt energijas pašizmaksa šīm stiebrzālēm attiecīgi bija par $13 \%$ un 19\% lielāka nekā timotinam (ar viszemāko enerǵijas pašizmaksu).

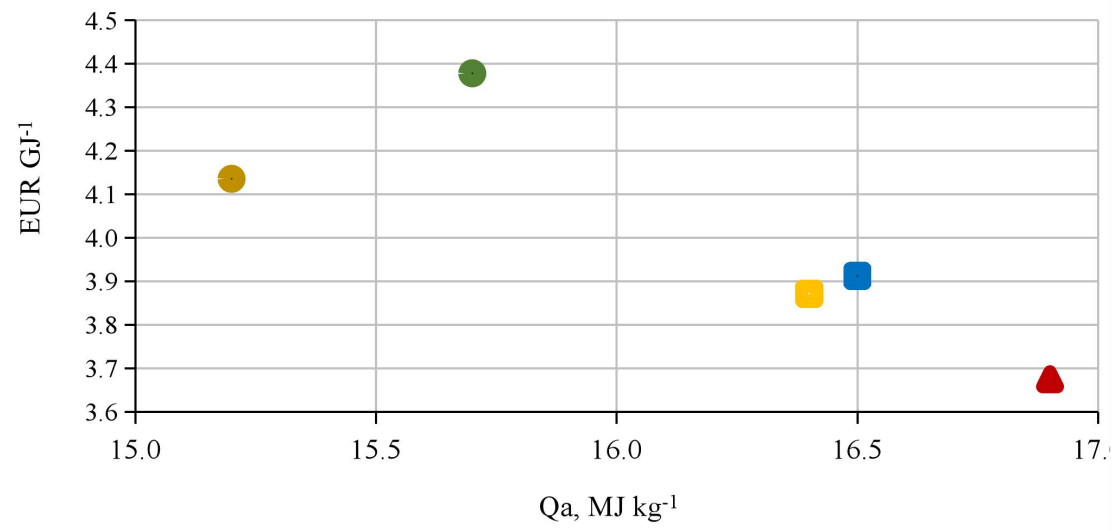

- - Niedru auzene / Tall fescue
- Miežabrālis / Reed canary grass
- Timotiňš / Timothy

- Plavas auzene / Meadow fescue
- Auzenairene / Festulolium

15. att. / Fig. 15. Stiebrzāḷu biomasas pašizmaksa (EUR GJ'-1) atkarībā no augstākās siltumspējas (vidēji 2012.-2013. g.). / The cost price of grass biomass (EUR $G J^{-1}$ ) depending on gross calorific value (average in 2012-2013).

\section{SECINĀJUMI}

1. Slāpekḷa minerālmēslojuma efektivitāte bija atšķirīga gan dažādām stiebrzāḷu sugām, gan dažādos zelmeṇa izmantošanas gados. Visos izmēǵinājuma variantos sausnas raža stiebrzālēm 1. izmantošanas gadā vidēji bija $6.08 \mathrm{t} \mathrm{ha}^{-1}$, 2. izmantošanas gadā tā palielinājās par 7\%, 3 . izmantošanas gadā - par $11 \%$, 4. izmantošanas gadā - par $18 \%$, un 5 . izmantošanas gadā - par 14\%. Slāpekḷa mēslojuma normu efektivitātes atšķirības pa zelmeņa izmantošanas gadiem apstiprina polinomu sadalījuma lineārie regresijas koeficienti. 
2. Augstākā sausnas raža no $1 \mathrm{~kg} \mathrm{~N}$ tika iegūta no kamolzāles un pḷavas auzenes, attiecīgi vidēji $60.4 \mathrm{~kg}$ un $29.0 \mathrm{~kg}$, ja tika lietota slāpekḷa mēslojuma norma $30 \mathrm{~kg} \mathrm{ha}^{-1} \mathrm{~N}$. Savukārt $60 \mathrm{~kg} \mathrm{ha}^{-1} \mathrm{~N}$ norma paaugstināja sausnas ražu no $1 \mathrm{~kg}$ lietotā $\mathrm{N}$ auzeṇairenei līdz $36.48 \mathrm{~kg}$, timotinam līdz $30.5 \mathrm{~kg}$, miežabrālim līdz $30.20 \mathrm{~kg}$ un niedru auzenei līdz $24.4 \mathrm{~kg}$.

3. Slāpekḷa izmantošanās efektivitāte no minerālmēsliem sausnas ražas ieguvei, lietojot $90 \mathrm{~kg} \mathrm{ha}^{-1} \mathrm{~N}$ mēslojuma normu, vidēji bija $61.3 \%$ timotinam, 50.6\% auzeñairenei, $41.7 \%$ plavas auzenei un $28.0 \%$ niedru auzenei; lietojot $60 \mathrm{~kg} \mathrm{ha}^{-1} \mathrm{~N}$ normu, slāpekḷa izmantošanās efektivitāte miežabrālim vidēji veidoja $40.3 \%$.

4. Augstākās stiebrzāḷu sausnas ražas no $1 \mathrm{~kg}$ NPK ieguva mēslojuma variantā $\mathrm{N}_{60} \mathrm{P}_{2} \mathrm{O}_{5} 80 \mathrm{~K}_{2} \mathrm{O} 120 \mathrm{~kg} \mathrm{ha}^{-1}$ : kamolzālei - $34.7 \mathrm{~kg}$, miežabrālim $27.0 \mathrm{~kg}$, auzeņairenei $-26.6 \mathrm{~kg}$, timotiņam $-26.1 \mathrm{~kg}$, niedru auzenei $25.8 \mathrm{~kg}$, plavas auzenei $-23.9 \mathrm{~kg}$.

5. Pelnu saturs stiebrzālēm nepārsniedza $8.92 \%$ pirmajā zelmeņa izmantošanas gadā un $7.91 \%$ otrajā izmantošanas gadā. Mazākais pelnu saturs koksnes un stiebrzāl̨u maisījuma proporcijā 3/1 bija kārklam ar auzeņaireni un miežabrāli (2.30-2.63\%) un kārklam un bērzam ar niedru auzeni $(2.5 \%)$.

6. Lielākā augstākā siltumspēja stiebrzālēm tika konstatēta no $15.24 \mathrm{MJ} \mathrm{kg}^{-1}$ niedru auzenei līdz $16.88 \mathrm{MJ} \quad \mathrm{kg}^{-1}$ timotiņam. Lielākā augstākā siltumspēja $\left(\geq 18.0 \mathrm{MJ} \mathrm{kg}^{-1}\right)$ biomasu maisījumiem bija bērzam un kārklam maisījumā ar miežabrāli, auzeņaireni un timotiņu proporcijā 3/1 ( $75 \%$ koksne $+25 \%$ stiebrzāles).

7. Augstākā pelnu kušanas sākuma temperatūra (DT) bija miežabrālim $\left(1240{ }^{\circ} \mathrm{C}\right)$, savukārt koksnes un zālaugu biomasu maisījumiem augstākās DT vērtības (lielākas par $1100{ }^{\circ} \mathrm{C}$ ) tika konstatêtas, kad koksnei pievienoja miežabrāli, auzeņaireni vai timotinu.

8. Saražotais enerǵijas daudzums stiebrzālēm bija robežās no $93.6 \mathrm{GJ}^{\mathrm{h}} \mathrm{ha}^{-1}$ pḷavas auzenei līdz 112.1 GJ ha-1 timotinam. No stiebrzālēm iegūtais enerğijas daudzums vidēji bija par $21 \%$ mazāks nekā no koksnes saražotais. Veidojot koksnes maisījumus ar stiebrzāl̨u sugām, vairāk enerğijas tika iegūts no niedru auzenes un timotiņa maisījumiem ar koksni proporcijā 3/1 (75\% koksne $+25 \%$ stiebrzāles): 141.9146.4 GJ ha ${ }^{-1}$.

9. Stiebrzāḷu sugām enerǵijas pašizmaksa bija robežās no 0.69 līdz 0.74 eirocentiem $\mathrm{kWh}^{-1}$, bet koksnei - no 0.28 eirocentiem $\mathrm{kWh}^{-1}$ bērzam līdz 0.8 eirocentiem $\mathrm{kWh}^{-1}$ hibrīdapsei. Koksnes un stiebrzāḷ biomasu maisījumiem enerğijas pašizmaksa variēja no 0.06 eirocentiem $\mathrm{kWh}^{-1}$ kārkla un bērza koksnes maisījumiem ar stiebrzālēm līdz 0.12 eirocentiem $\mathrm{kWh}^{-1}$ apses maisījumiem ar stiebrzālēm. Enerǵijas pašizmaksu stiebrzālēm ietekmēja arī minerālmēslojuma normas. 


\section{PRIEKŠLIKUMI}

1. Paplašinot stiebrzāḷu izmantošanas spektru - ne tikai tradicionāli lopbarībai (zaḷmasa, siens, skābbarība, zāles milti), bet arī enerǵētikā (biogāze, kurināmais) - un izvērtējot stiebrzāḷ biomasas siltumtehniskos rādītājus, tika apstiprināta hipotēze: stiebrzāles ar labām sekmēm var izmantot kā cietā kurināmā izejvielu, kas atbilst Latvijas standartu prasībām.

2. Tā kā koksnes biomasa ir lēni augoša un to var iegūt periodiski, bet stiebrzāḷu biomasu var ražot ik gadu, tad ar stiebrzāḷu biomasas izmantošanas potenciāla palīdzību iespējams dal̦ēji atrisināt nepieciešamos biomasas resursus (kā izejvielu) siltuma enerǵijas ražošanai.

3. Kurināmā izejvielu iegūšanai stiebrzāḷ un koksnes biomasu maisījumu ieteicams veidot, pievienojot tam līdz 25\% stiebrzāḷ biomasas.

4. Iegūtie siltumtehniskie parametri norāda, ka perspektīvākās stiebrzāles cietā kurināmā ieguvei ir kamolzāle, miežabrālis, timotiņš un auzeņairene, tādēl ieteicams tās izmantot kā piedevas koksnes granulu ražošanā.

\section{THE TOPICALITY OF THE RESEARCH}

At present, the energy potential of biomass is estimated to be around 10$14 \%$ of the world's total energy consumption (Putun, Ozcan, Gercel et al., 2011; Offermann, Brunner, Barnthaler et al., 2011; Venkata, 2014). Research on the use of renewable energy sources is current worldwide, incl. Europe and Latvia.

In recent studies, the use of perennial grasses for the production of biofuel is considered to be more promising than annual crops (Lewandovski, Scurlock, Lindvall et al., 2003; Jasinsk, Zaltauskas, Kryzeviciene, 2008; Prochnow, Heiermann, Plöchl et al., 2009). Studies have shown that the calorific value of a fuel depends on the diversity of grass species (Khalsa, 2013).

This study examines only a small part of the perennial grasses biomass types - cereal grasses, which are considered to be the most promising source of renewable resources, with the corresponding energy qualities with a sufficiently high calorific value. Cereal grasses biomass can be used in the production of solid fuel pellets and briquettes. The disadvantage of cereal grasses biomass is its high ash yield, and its physical, mechanical and chemical properties depend on the grass variety, soil and climatic conditions, the type and amount of fertilizers used as well as the density of plants, and the time of harvest. It is important to clarify the suitability of the biomass of certain cereal grass species for local conditions in order to find the optimal biomass application (in pure form or in mixtures) for the production of solid fuels. The thesis examines the use of cereal grass species suitable for Latvian conditions for mixing with 
timber and analyses solid fuel energy values, considering also the economic aspect.

For bio-energy, the most suitable grasses are reed canary grass (Phalaris arundinacea (L.) Raush.), tall fescue (Festuca arundinacea Schreb.), festulolium ( $\times$ Festulolium Asch \& Graebn.), cocksfoot grass (Dactylis glomerata $\mathrm{L}$.) and other cereal grass species.

Compared to other types of alternative energy, granulated grass biomass can become an important fuel source for the production of heat in Latvia. For example, in Latvia there is a sufficient potential for the use of fuel timber, however, wood resources can decrease rapidly in the future due to a slow recovery (depending on the species of trees, it takes at least 20 to 60 years). In addition, it would be wise to use timber more sensibly. Cereal grasses have a great potential as a renewable energy source, since biomass, which is useful for growing, grows during one vegetation season and can be processed and consumed at the place of production. Within the framework of the dissertation, in order to obtain optimum composition and high energy biofuels for Latvian conditions, the author studies mixes of timber and grass biomass in various proportions $(1 / 3,1 / 1$ and $3 / 1)$ for the production of granules for heating in Latvia.

Hypothesis: Cereal grass biomass and its mixtures with timber according to the thermal-technical characteristics are suitable for production of solid fuels.

The aim of the work: to evaluate possibilities of using cereal grasses biomass for production of solid fuels.

\section{Objectives:}

1. to evaluate yield of cereal grasses at various nitrogen fertilizer rates;

2. to determine the thermal-technical parameters of cereal grasses biomass and to assess their suitability for production of solid fuels;

3 . to find the most suitable proportions of cereal grasses and timber biomass for the formation of granules;

4. to determine the energy content of biomass of cereal grasses, timber and their mixtures and estimate costs of the fuel.

\section{Study novelty:}

- specified biomass of cereal grasses for fuel production;

- for the first time, the compliance of the thermal-technical parameters of the ratio of grasses and timber biomass with the requirements of solid fuel quality is analysed.

\section{Thesis defence:}

- cereal grasses have good energetic qualities and a sufficiently high calorific value;

- cereal grasses biomass can be used for the production of solid fuel pellets and briquettes;

- The amount of energy produced depends on the choice of grasses and timber species, as well as on the proportion of them in mixtures. 
Originality of the research. For the first time, the author analyses the impact of fertilizers on the yield of cereal grasses, the chemical composition of the dry matter and energy indicators, as well as their impact on mixtures of these grasses and timber biomass, having different proportions with timber of different species of trees, and their compliance with the requirements of the biofuel standard quality, from an energy point of view.

The practical and theoretical significance of the research results. Cereal grasses, in comparison with trees, have their own growth rhythm, requirements for the growth medium and fertilizer, they differ in the thermaltechnical properties that are affected by the choice of agro-technology and the type of harvest. The results obtained in the study allow to improve cereal grass cultivation technology in accordance with fuel quality requirements and to make more precise decisions on the choice of culmiferous species for cultivation under specific agro-climatic conditions. The information gathered in the study adds to the knowledge of the efficiency of the biofuel production process. The obtained results are useful for calculating the energetic potential of cereal grass and timber pellets, taking into account the fact that the biomass value changes depending on the type of the cereal grass, the fertilizer and the specific characteristics of the meteorological conditions of the year.

Benefits from the results of the study. The experience accumulated and described in the study will allow expanding the spectrum of use of cereal grasses, not only as traditionally used in agriculture for fodder production, but also in addition to energy production for biofuel. The obtained results demonstrate the most useful types of biomass mixtures of timber and cereal grasses and their proportions.

\section{STUDY CONDITIONS AND METHODS}

The field trials were conducted in 2011 at the Peterlauki Study and Research Farm $\left(56^{\circ} 53^{\prime} \mathrm{N}, 23^{\circ} 71^{\prime} \mathrm{E}\right)$ of the Latvia University of Life Sciences and Technologies. The study was conducted from 2012 to 2016.

The soil type: sod calcareous soil (Endocalcaric Luvisol according to the FAO classification). Grain size composition: heavy dusty sand clay. Soil agrochemical parameters: pH KCL 6.7 (LVS ISO 10390: 2006), organic matter content $21 \mathrm{~g} \mathrm{~kg}^{-1}$ (according to Tyurin method, LV ST ZM 80-91), phosphorus content $52 \mathrm{mg} \mathrm{kg}^{-1} \mathrm{P}_{2} \mathrm{O}_{5}$ (low) and potassium content $128 \mathrm{mg} \mathrm{kg}^{-1} \mathrm{~K}_{2} \mathrm{O}$ (medium) (by Egner-Rhyming method; LV ST ZM 82-97).

The pre-plant was summer barley - grown for two consecutive years as a counterweight. After pre-crop harvesting, the soil was ploughed in the autumn, $22 \mathrm{~cm}$ deep. In the spring, when the soil reached its physical-mechanical readiness, it was first splashed, then cultivated. 
The experiment was carried out with six types of cereal grasses: reed canary grass (Phalaris arundinaceae (L.) Raush.), cultivar 'Marathon'; festulolium ( $\times$ Festulolium Asch. \& Graebn.), the cultivar 'Vetra'; timothy (Phleum pratense L.), cultivar 'Teicis'; meadow fescue (Festuca pratensis Huds.), cultivar 'Vaira'; tall fescue (Festuca arundinaceae Schreb.), cultivar 'Fawn'; and cocksfoot grass (Dactylis glometata L.), the cultivar 'Priekuli 30'.

The seedling rate for cereal grass species was 1000 germinating seeds per $1 \mathrm{~m}^{2}$ with the respective amount per 1 ha: reed canary grass $-10.0 \mathrm{~kg}$ for festulolium $-9.5 \mathrm{~kg}$ for timothy $-13.0 \mathrm{~kg}$ for meadow fescue $-12.5 \mathrm{~kg}$ for tall fescue $-17.0 \mathrm{~kg}$ and cocksfoot grass $-18.0 \mathrm{~kg}$. Cereal grasses were sown on May 10, 2011, unpeeled, with seed-driller Hege-80.

The following fertilizer variants were used for all types of cereal grasses: N0P0K0 - control, P80K120 - background fertilizer (F), and six pre-plant fertilizer variants with nitrogen fertilizer rates: $F+30, F+60, F+90, F+120$, $\mathrm{F}+150$ and $\mathrm{F}+180 \mathrm{~kg} \mathrm{ha}^{-1} \mathrm{~N}$.

The experiment contained 48 variants. The field area was $10 \mathrm{~m}^{2}$, with $2 \mathrm{~m}$ wide aisle between cereal grass species. The option layout was randomized.

Harvesting and sample preparation. Crop accounting began for 2012 for the research purposes ( $1^{\text {st }}$ year of use). The following years of use of the grassland were: 2013 - the second year of use; 2014 - 3rd year of use; 2014 $4^{\text {th }}$ year of use; $2016-5^{\text {th }}$ year of use. Harvesting was carried out by cutting the grass between 5 and $6 \mathrm{~cm}$ high with the grass harvester HANS - ULRICH HEGE 212, the weight of the green mass weight was calculated electronically, determining the yield of each replicate in the field.

For each species and fertilizer variant, $1.5-2.0 \mathrm{~kg}$ green mass samples were taken in three replicates. They were cut in $2-3 \mathrm{~cm}$ long pieces; for each variant, average samples of $1 \mathrm{~kg}$ mass, accurate to $\pm 0.01 \mathrm{~kg}$, for physical and chemical analysis were prepared. The dry matter content of the green mass samples was determined by drying them at $105^{\circ} \mathrm{C}$ to a constant mass (LVL EN ISO 721: 2010).

Dry matter yields calculated in each variant were expressed as average arithmetic values from three replicates and compared with each other as the absolute deviation $\pm\left(\mathrm{t} \mathrm{ha}^{-1}\right)$ and relative deviation $(\%)$. In order to determine the effect of the nitrogen fertilizer, the actual values of the fertilizer variant were compared with (1) non-fertilizer control and with (2) the background variant (P80K120) in which nitrogen fertilizers were not used.

Characteristics of meteorological conditions. For the period from $01 / 01 / 2011$ to $31 / 12 / 2016$, the data about air temperature and rainfall were obtained from the automatic Meteorological station at the Peterlauki Study and Research Farm of the Latvia University of Life Sciences and Technologies. For comparison of the annual meteorological data; the long-term average temperature and precipitation data (norm) were used from the Jelgava meteorological station. 
Climatic conditions affect grass hibernation and growing of grassland and determine the size of the crop. The length of the wintering period varied from 128 days in 2013/2014 to 173 days in 2012/2013. During the five-year period, only two winters had a negative average air temperature. The coldest winter was in $2012 / 2013$, when the average temperature dropped to $-2.5^{\circ} \mathrm{C}$, whereas the warmest winters were in 2014/2015 and 2015/2016, when the average temperature in the wintertime reached or exceeded $+1.0{ }^{\circ} \mathrm{C}$.

In the vegetation period, the amount of precipitation corresponded to the norm in 2011, 2012 and 2014, when it was consistent with the average observed on a long-term basis, but in 2013, 2015 and 2016 it was significantly lower than the norm.

Solid fuel biomass granules were made from ground cereal grasses and timber biomass. For the formation of pellets, dry powder mixtures were used consisting of the following components: grasses (reed canary grass, festulolium, tall fescue, timothy, meadow fescue) and timber (birch (Betula pendula Roth.), osier (Salix spp.), grey alder (Alnus incana (L.) Moench), aspen (Populus tremula L.) and hybrid aspen (Populus tremuloides $\times$ Populus tremula)).

The timber biomass was obtained from the State Forest Research Institute Silava (located in Salaspils) - in the form of powder, with a particle diameter $<1 \mathrm{~mm}$.

The grass and timber pulp was pressed in granules with the hand press IKA WERKE. The two component granules were composed of the following components:

(I) ratio $1 / 3(25 \%$ timber $+75 \%$ grasses $)$;

(II) ratio $1 / 1(50 \%$ timber $+50 \%$ grasses $)$;

(III) proportion $3 / 1$ (75\% timber $+25 \%$ grasses) .

One component $(100 \%)$ granules of grasses and timber pulp were used for control.

The energy value of the pellets was calculated using the following formula (1):

where $\mathrm{Q}_{\mathrm{kop}}$ - total amount of energy obtained from 1 ha, $\mathrm{MJ} \mathrm{ha}^{-1}$;

$\mathrm{Q}_{\mathrm{a}}$ - gross calorific value of biomass dry matter, in $\mathrm{MJ} \mathrm{kg}^{-1}$;

$\mathrm{M}_{\mathrm{s}}$ - dry matter of biomass of 1 hectare, $\mathrm{kg} \mathrm{ha}^{-1}$.

The cost of energy for pellets was calculated according to the following formula (2):

where $p_{e}-$ cost of energy (on dry basis), Eur $\mathrm{MJ}^{-1}$;

$\mathrm{P}_{\mathrm{m}}$ - biomass 1 tonne dry matter extraction cost, Eur $\mathrm{t}^{-1}$;

$\mathrm{Q}_{\mathrm{a}}$ - highest heating value of biomass dry matter, in $\mathrm{MJ} \mathrm{kg}^{-1}$.

Chemical and energy indicators and properties were assessed to evaluate the suitability of granules of grass and wood biomass and their mixtures for use as solid fuels for heat production. The analyses were carried out at the Laboratory of Agronomic Analysis of the Latvia University of Life Sciences 
and Technologies and Virsma, Laboratory for Research and Testing on Waste and Fuel. The methods used are given in tables 1 and 2 .

The physical properties of the investigated cereal grass biomass fuel were evaluated in comparison with the requirements specified in the standard LVS EN 14961-2-2012 (LVS EN ISO 17225-6: 2014) for reed canary grass (one of the first grasses that started to be used as an energy plant), whereas the physical properties of timber biomass fuel were compared to the requirements specified in standard LVS EN 14961-6-2012 (LVS EN ISO 17225-2: 2014) for whole trees without roots as well as tree trunks.

Data mathematical processing. The data were mathematically processed with Microsoft Excel for Windows 2000 and SPSS packages. These programs also produce relevant coefficients, equations, and graphic images.

The obtained study results were statistically processed using descriptive statistics (mean arithmetic, minimum and maximum values, $\mathrm{Sx}$ - mean arithmetic representation error, $\mathrm{Sd}$ - difference representation error) and variation statistics at 95\% confidence level, as well as correlation and factor analysis methods were used. Materiality significance was used to measure the significance of the factors. Materiality level was $p<0.05$. A multiplicity linear regression analysis was used to determine the effect of the variables on the dependent variable. Data analysis is represented by linear regression curves and equations. The effect of the nitrogen fertilizer norm on the energy crop productivity was estimated by linear regression equations and determination coefficient $\left(\mathrm{R}^{2}\right)$. The effect of nitrogen fertilizer norms on yield of grasses is analysed and shown in polynomial relationships in the corresponding nitrogen norm (ayx and byx) and described with linear regression coefficients and corresponding linear regression equations for polynomial linear definition regions. The gross calorific value of cereal grass and timber biomass was used to calculate the amount of energy produced.

\section{RESULTS}

\section{The Effect of Fertilizer on Grass Dry Matter Yield}

The yield of the cereal grasses species included in the study was influenced both by the climatic conditions of the year and the use of mineral fertilizers.

In the non-fertilized variant of the first harvest, the yield of the dry matter yield of the reed canary grass was $3.67 \mathrm{tha}^{-1}$ to $5.73 \mathrm{tha}^{-1}$, and the dry matter yield increased with each subsequent year of use, for tall fescue - from $4.23 \mathrm{t} \mathrm{ha}^{-1}$ to $5.51 \mathrm{t} \mathrm{ha}^{-1}$ with the maximum yield in the fourth year of use, for festulolium - from $3.87 \mathrm{t} \mathrm{ha}^{-1}$ to $4.51 \mathrm{t} \mathrm{ha}^{-1}$ with a maximum yield in the third year of use, for timothy - from $2.99 \mathrm{t} \mathrm{ha}^{-1}$ to $4.38 \mathrm{t} \mathrm{ha}^{-1}$ with the highest dry crop in the third year of use, for meadow fescue - from $2.72 \mathrm{t} \mathrm{ha}^{-1}$ to $4.01 \mathrm{t} \mathrm{ha}^{-1}$ 
with the maximum yield in the third year of use and from the cocksfoot grass from $5.18 \mathrm{tha}^{-1}$ to $5.27 \mathrm{t} \mathrm{ha}^{-1}$.

Nitrogen fertilizers have had a positive effect on the growth of dry crop in all grasses during all years of its use, but not all crop growth was significant or cost effective.

In the variants of nitrogen mineral fertilizers, the average dry matter yield was averaged from $6.18 \mathrm{t} \mathrm{ha}^{-1}$ (lowest level), whereas the highest level was $9.62 \mathrm{t} \mathrm{ha}^{-1}$. The use of nitrogen fertilizer for grasses averaged over all years of use of grassland, which resulted in the following increase in dry matter yield: cocksfoot grass $-3.48 \mathrm{t} \mathrm{ha}^{-1}$ ( $57 \%$ compared to non-nitrogen fertilizer), for timothy $-2.55 \mathrm{t} \mathrm{ha}^{-1}(+51 \%)$, for meadow fescue $-2.33 \mathrm{ha}^{-1}(+52 \%)$, for festullolium $-2.24 \mathrm{t} \mathrm{ha}^{-1}(+57 \%)$, for tall fescue $-1.99 \mathrm{t} \mathrm{ha}^{-1}(+38 \%)$ and for reed canary grass $-1.93 \mathrm{t} \mathrm{ha}^{-1}(+37 \%)$

The results of the experiment show that tall fescue and festulolium were responsive to nitrogen fertilization and the increase in nitrogen content also significantly increased the dry matter yield (Fig. 1).

In the first year of use of tall fescue, the increase in yield $(p<0.05)$ was significant when nitrogen norm of $60 \mathrm{~kg} \mathrm{ha}^{-1} \mathrm{~N}$ was used, then the dry matter yield reached $6.15 \mathrm{tha}^{-1}$. A further increase of nitrogen norm up to $180 \mathrm{~kg} \mathrm{ha}^{-1}$ $\mathrm{N}$ contributed to a significant increase in yield - even $8.64 \mathrm{t} \mathrm{ha}^{-1}$ of dry matter. Also, the increase of dry matter yield $(p<0.05)$ for festulolium continued to increase to $180 \mathrm{~kg} \mathrm{ha}^{-1} \mathrm{~N}$, providing $8.11 \mathrm{t} \mathrm{ha}^{-1}$ of dry matter yield. In the following years, with the development of a denser sward, festulolium yielded a dry matter of $>8.0 \mathrm{t} \mathrm{ha}^{-1}$ with lower nitrogen norms than it was required in the first year of use.

In the second year of sward of tall fescue, in its second year of use of the grassland, a significant increase $(p<0.05)$ was observed at the nitrogen norm of $30 \mathrm{~kg} \mathrm{ha}^{-1} \mathrm{~N}$ and the increase in the nitrogen norm continued to provide a significant yield increase of up to $60 \mathrm{~kg} \mathrm{ha}^{-1} \mathrm{~N}$, but a further increase in the nitrogen norm resulted in an insignificant crop growth. Also, in the third year of the use of grassland, tall fescue gained a significant increase in dry crop at the nitrogen norm of $30 \mathrm{~kg} \mathrm{ha}^{-1} \mathrm{~N}$, as well as at fertilization rates of 120 and $180 \mathrm{~kg} \mathrm{ha}^{-1} \mathrm{~N}$. In the fourth year of the use of grassland, a significant increase $(p<0.05)$ was gained at nitrogen norms 60,120 and $180 \mathrm{~kg} \mathrm{ha}^{-1} \mathrm{~N}$. In the fifth year of the use of the grassland, a significant increase in yield was obtained at nitrogen norm of 60 and $120 \mathrm{~kg} \mathrm{ha}^{-1} \mathrm{~N}$.

From the agronomic point of view, in the first year of use of the tall fescue, it is necessary to use high nitrogen norms $\left(>150 \mathrm{~kg} \mathrm{ha}^{-1} \mathrm{~N}\right)$ in order to exceed the yield of dry matter $8.0 \mathrm{t} \mathrm{ha}^{-1}$. With the age of grassland, when it becomes stronger and denser to hold a dry matter of over $8.0 \mathrm{t} \mathrm{ha}^{-1}$, it is necessary for tall fescue to use nitrogen $120 \mathrm{~kg} \mathrm{ha}^{-1} \mathrm{~N}$ and more.

With the help of linear decomposition of polynomials, the study determined interaction effects of factors, i.e. how the years of use and growth 
conditions affected the efficiency of increasing nitrogen fertilizer norms and to what extent it was useful to increase them (Fig. 2).

Using linear regression coefficients it was found that tall fescue achieved the highest nitrogen efficiency at the nitrogen norm of $180 \mathrm{~kg} \mathrm{ha}^{-1} \mathrm{~N}$ in the first year of use of the grassland, in the second and fourth year with the nitrogen norm $60 \mathrm{~kg} \mathrm{ha}^{-1} \mathrm{~N}$, in the third - with the nitrogen norm of $30 \mathrm{~kg} \mathrm{ha}^{-1}$ $\mathrm{N}$ and in the fifth - with a nitrogen norm of $120 \mathrm{~kg} \mathrm{ha}^{-1} \mathrm{~N}$.

The evaluation of linear coefficients confirmed fluctuations in the significance of the previously observed and described dry matter yields. In its turn, the highest efficiency of increasing nitrogen norms in the first year of use of the grassland for festulolium was achieved with nitrogen norm of $120 \mathrm{~kg} \mathrm{ha}^{-1}$ $\mathrm{N}$, in the second $-30 \mathrm{~kg} \mathrm{ha}^{-1} \mathrm{~N}$ and from the third to the fifth year of use of grassland with $60 \mathrm{~kg} \mathrm{ha}^{-1} \mathrm{~N}$.

Timothy dry matter yield was significantly increased $(p<0.05)$ by nitrogen fertilizer (Fig. 4). Already at the nitrogen norm of $30 \mathrm{~kg} \mathrm{ha}^{-1} \mathrm{~N}$, the yield of dry matter, on average during three years, reached $5.86 \mathrm{t} \mathrm{ha}^{-1}(+18 \%)$. Using nitrogen fertilizer at the rate of $180 \mathrm{~kg} \mathrm{ha}^{-1} \mathrm{~N}$ in the background of phosphorus and potassium fertilizers, on average over three years, made it possible to obtain a yield of $8.60 \mathrm{tha}^{-1}$, which was 2.27 times higher than that in which the fertilizer was not used. In all three years of use of timothy, nitrogen at the rate of $180 \mathrm{~kg} \mathrm{ha}^{-1} \mathrm{~N}$ gave the highest yields: from $2.70 \mathrm{t} \mathrm{ha}^{-1}(+$ $47 \%)$ to $4.59 \mathrm{t} \mathrm{ha}^{-1}(+118 \%)$.

Meadow fescue was responsive to nitrogen fertilizer, which allowed significantly $(p<0.05)$ to increase the yield of dry matter. Starting with a nitrogen norm of $30 \mathrm{~kg} \mathrm{ha}^{-1} \mathrm{~N}$, and with each subsequent step of the nitrogen norm, the dry matter yield increased substantially and the highest dry matter yield was $8.13 \mathrm{t} \mathrm{ha}^{-1}$ (on average for three years) using a nitrogen norm of $180 \mathrm{~kg} \mathrm{ha}^{-1} \mathrm{~N}$ (Fig. 4)

Reed canary grass dry matter yields obtained maximum with a nitrogen norm of $60 \mathrm{~kg} \mathrm{ha}^{-1} \mathrm{~N}$ in all the years of use (Fig. 4), but a further increase in the norm did not result in a significant increase in yield.

By linear regression of polynomials, using linear regression coefficients, it was found that nitrogen fertilizer highest efficiency for the timothy during the years of use varied. In the first year of use, the highest nitrogen efficiency was reached with nitrogen rate of $30 \mathrm{~kg} \mathrm{ha}^{-1} \mathrm{~N}$ (Fig. 5), whereas in the second year, nitrogen was needed much more $-120 \mathrm{~kg} \mathrm{ha}^{-1} \mathrm{~N}$, and in the third year the highest effectiveness was reached at a nitrogen level of $60 \mathrm{~kg} \mathrm{ha}^{-1}$.

Using linear regrouping of polynomials, linear regression coefficients showed that the highest efficiency of nitrogen increase in the meadow fescue during the first and third year of use of the grassland was with a nitrogen norm of $30 \mathrm{~kg}$ ha-1 $\mathrm{N}$ (Fig. 6) and in the second - with a nitrogen norm of $60 \mathrm{~kg}$ ha-1 $\mathrm{N}$. 
Using linear regression of polynomials, the coefficients revealed that the reed canary grass achieved the highest nitrogen fertilizer efficiency at a nitrogen norm of $60 \mathrm{~kg}$ ha- $1 \mathrm{~N}$ in the first and second year of use of the grassland, and in the third year it was sufficient to use the nitrogen norm of $30 \mathrm{~kg}$ ha-1 N (Fig. 7).

\section{Fertilizer Efficiency in Grass Growing}

For cereal grass, the highest nitrogen efficiency from $1 \mathrm{~kg}$ nitrogen was achieved using low nitrogen norms of $30-60 \mathrm{~kg} \mathrm{ha}^{-1} \mathrm{~N}$ (Fig. 8).

Using average nitrogen fertilizer norms (from 90 to $120 \mathrm{~kg} \mathrm{ha}^{-1} \mathrm{~N}$ ), the amount of dry matter yield obtained in almost all cases decreased, with the exception of timothy in the second year of use. Using high nitrogen fertilizer rates $\left(150-180 \mathrm{~kg} \mathrm{ha}^{-1} \mathrm{~N}\right)$ showed a steady increase in dry matter growth during the first year of use of grassland. The obtained results showed that tall fescue was the most sensitive species of grasses to nitrogen fertilizer at the beginning of the development, when the dry matter yield per $1 \mathrm{~kg} \mathrm{~N}$ increased at all levels of $\mathrm{N}$ rates.

In the first year of use of the grassland, timothy used nitrogen better with low nitrogen fertilization rates than using medium and high norms, but tall fescue had higher utilization efficiency at high nitrogen norms. In the second year of use of grassland, for both cereal grass species, the use of nitrogen was in proportion to the reverse position in the first year of use.

The use of the highest nitrogen nutrients for reed canary grass was detected with a nitrogen fertilizer norm of $60 \mathrm{~kg} \mathrm{ha}^{-1} \mathrm{~N}$ (mean $37.2 \%$ ).

On average, timothy used nitrogen from 41.7 to $43.1 \%$ at nitrogen rate of $90-120 \mathrm{~kg} \mathrm{ha}^{-1} \mathrm{~N}$ in the two years of use, despite the differences in growing conditions. The average nitrogen utilization of the meadow fescue was observed on average for two years with a nitrogen norm of $60 \mathrm{~kg} \mathrm{ha}^{-1} \mathrm{~N}$ $41.8 \%$.

\section{Evaluation of Grass Biomass Fuel Quality Indicators}

The moisture content of biomass is variable and it affects the quality and cost of fuel. In order to reduce the moisture content, it is necessary to invest a significant amount of energy, which forms one of the largest expenditure positions in the fuel production process. In the study, prior to pelletizing, the moisture content of grasses was $9.00 \%$ (from $8.10 \%$ of meadow fescue to $10.40 \%$ of festulolium), but for timber $-7.82 \%$ (from $7.00 \%$ for osier to $8.50 \%$ for hybrid aspen and birch) and met standard requirements. The moisture content of cereal grass and timber biomass mixtures was also below $10 \%$, and 
the moisture content decreased as the amount of wood increased. Adding 1/3 of timber biomass mixture decreased the moisture content by $5 \%$ on average, but adding half or $2 / 3$ of timber, moisture of the mixture decreased by $15 \%$ and $20 \%$, respectively.

The ash builds melt particles, which results in a faster obstruction of the combustion chamber and convective part of the boiler and therefore more frequent mechanical cleaning is required.

The average ash content of cereal grass biomass ranged from $6.60 \%$ for timothy to $8.05 \%$ for tall fescue, which is close to the ash content mentioned in different other sources (Beidermann, Obernberger, 2005; Bakker, Elbersen, 2005).

The lowest ash content for grass biomass was detected from $4.99 \%$ for timothy in 2013 to $7.93 \%$ for tall fescue in 2012 , and the highest from $6.83 \%$ for timothy in 2013 to $8.92 \%$ tall fescue in 2012 . On average, from all the fertilizer variants included in the experiment, the ash content was $8.05 \%$ for tall fescue, $7.36 \%$ for reed canary grass, $7.27 \%$ for festulolium, $7.14 \%$ for meadow fescue and $6.60 \%$ for timothy.

Standard requirements stipulate that the ash content of the reed canary grass biomass cannot exceed $8.0 \%$. Nutrient nitrogen norms $\geq 60 \mathrm{~kg} \mathrm{ha}^{-1} \mathrm{~N}$ for reed canary grass have contributed to a decrease in the ash content below the standard size of $8.0 \%$ for both years of use of grassland. For other cereal grasses such as festulolium and timothy, the ash content was below $8.0 \%$, and in some cases the observed deviation was not explained as a probable regularity.

Regression analysis showed that the ash content increased with potassium $\left(\mathrm{R}^{2}=0.86 ; p=0.01\right)$, phosphorus $\left(\mathrm{R}^{2}=0.62 ; p=0.01\right)$, chlorine $\left(\mathrm{R}^{2}=0.71 ; p=\right.$ $0.01)$ and nitrogen $\left(\mathrm{R}^{2}=0.74 ;{ }^{\mathrm{p}}=0.01\right)$ in dry matter of biomass. This is due to the fact that these elements form constituent compounds in the ash in the burning process of the biomass fuel (Vassilev, Vassilev, Song et al. 2017).

Ash content in cereal grasses and timber compositions decreases in proportion to the increase in timber share, because on average, timber biomass has $70-80 \%$ less ash compared to grasses. The analysis of the composition of grass and timber biomass shows that the grasses, after adding one third of timber, reduce the ash content by $20 \%$, whereas a mix of $1 / 1$ or two thirds of timber reduce ash content by $40 \%$ and $55 \%$, respectively. The best (lowest) ash content was observed in festulolium and reed canary grass mixture $(1 / 3)$ with osier $-2.30 \%$ and $2.63 \%$, tall fescue and osier or birch $-2.5 \%$ and timothy with grey alder $-2.9 \%$ (Fig. 9)

When assessing the suitability of cereal grasses for fuel production, it should be taken into account that the ash content may change from year to year, also due to other factors, but proportional changes remain. Observations indicate dependence of ash content on species and agro meteorological conditions. 
Carbon (C) is one of the chemical elements that determines the amount of heat energy generated by the fuel. Carbon content in plants is an important indicator because $\mathrm{C}$ is a combustible element. The higher the carbon content of the plant, the higher the combustion heat.

The carbon content of the studied cereal grasses was on average from $44.5 \%$ in tall fescue to $45.3 \%$ in timothy. The carbon content of reed canary grass dry matter on average was $45.11 \%$ in all variations (from $42.69 \%$ in 2013 to $47.58 \%$ in 2012). On average, the content of $\mathrm{C}$ in reed canary grass dry matter was $45.11 \%$ (from $42.69 \%$ in 2013 to $47.58 \%$ in 2012). The $\mathrm{C}$ content of non-fertilized yield was $44.93 \%$ on average (from $42.90 \%$ to $47.43 \%$ ).

In the samples of timber, the highest carbon content was in aspen $48.90 \%$, but the lowest in birch $-46.10 \%$. Carbon content in cereal grasses in the $1^{\text {st }}$ and $2^{\text {nd }}$ year of use varied from $42.00 \%$ of meadow fescue in 2013 to $48.97 \%$ of timothy in 2012 .

Summarizing the results for all types of cereal grasses, that is, in variants using nitrogen fertilizers $\geq 120 \mathrm{~kg} \mathrm{ha}^{-1} \mathrm{~N}$, the carbon content was on average above $45 \%$.

The highest carbon content of festulolium was in a mix with osier, in proportion $1 / 3-46.6 \%$, reed canary grass mix with grey alder $-46.9 \%$. On the other hand, the lowest rates were for festulolium (3/1) with hybrid aspen $(43.7 \%)$ and reed canary grass (3/1) with osier (43.4\%).

The hydrogen content $(\mathbf{H})$ in the fuel determines its calorific value: the more hydrogen, the higher the calorific value.

The hydrogen content in the analysed timber and cereal grass samples was from $5.48 \%$ for timothy to $5.93 \%$ for tall fescue, and from $6.39 \%$ for grey alder to $6.83 \%$ for birch. The hydrogen content of the studied cereal grasses was on average $6 \%$ lower than that of timber biomass samples. In general, the hydrogen content was similar in the studied biomass, in the cereal grasses $\mathrm{H}$ content variation was within $10 \%$. Hydrogen content was on average higher in timber biomass.

The H/C ratio (1.51-1.52) of some grasses such as festulolium, reed canary grass and tall fescue was similar to that of aspen, hybrid aspen and grey alder biomass $(\mathrm{H} / \mathrm{C}-1.52)$. The highest $\mathrm{H} / \mathrm{C}$ index was for osier and birch 1.54. $\mathrm{H} / \mathrm{C}$ index increased in aspen mixture with cereal grasses with the increase in the amount of timber, but the increase in $\mathrm{H} / \mathrm{C}$ is not high, $0.5 \%$ to $2 \%$.

Hydrogen and carbon content indicates the energy content of the fuel, which is characterized by the atomic ratio $\mathrm{H} / \mathrm{C}$ of these elements. The more hydrogen in relation to carbon, the lower the degree of oxidation, the more energy will be released in the oxidation reaction. So, the higher the atomic $\mathrm{H} / \mathrm{C}$ ratio, the more energy is released in the fuel burning process. The average $\mathrm{H} / \mathrm{C}$ ratio for lignocellulosic biomass is 1.5 (Lehmann, Joseph, 2009). In this study, the highest ratio of $\mathrm{H} / \mathrm{C}$ among the cereal grasses was 1.52 for tall fescue and 
the lowest 1.45 for timothy. Among the timber biomass, the highest ratio of $\mathrm{H} / \mathrm{C}$ was in birch - 1.54. In general, the $\mathrm{H} / \mathrm{C}$ ratio did not differ radically for the biomass studied, the average $\mathrm{H} / \mathrm{C}$ ratio for cereal grasses was $2.3 \%$ lower than for timber.

Nitrogen (N), when fuel is combusted, forms volatile nitrogen compounds that enter the atmosphere with untreated flue gases, therefore, in vegetation biomass as a fuel should not exceed 0.6\% (Obernberger, Brunner, Barnthaler, 2006). In its standard (LVS EN 14961 - 2 - 2012 (LVS EN ISO 17225 - 6: 2014), the nitrogen content in the dry matter cannot exceed $2.0 \%$.

In the culm, the nitrogen content, depending on the year and the species of cereal grasses, ranged from $0.63 \%$ of the meadow fescue in 2012 to $2.59 \%$ of the meadow fescue in 2013. On average, from all fertilizer variants of the experiment, the nitrogen content of the meadow fescue was $1.71 \%$, timothy $-1.32 \%$, festulolium $-1.18 \%$, reed canary grass $-1.13 \%$, and tall fescue $-1.05 \%$.

The nitrogen content in the timber samples was $0.3 \%$ to $0.6 \%$, whereas reed canary grass and festulolium were $1.3 \%$ and $1.1 \%$, respectively.

In the timber and cereal grass mixture, the nitrogen content increased with the increase in the proportion of cereal grasses in it. In the proportion of the mixture 3/1 (75\% timber and $25 \%$ grasses), the $\mathrm{N}$ content increased on average by $23 \%$, but in proportions $1 / 1$ and $1 / 3$ - by $36 \%$ and $56 \%$, respectively.

The greatest reduction in the nitrogen content was achieved in biomass mixtures $3 / 1$ (timber / grasses) - festulolium $80 \%(0.42 \%)$, reed canary grass $-70 \%$ $(0.49 \%)$ in a mixture with osier. The lowest nitrogen content for cereal grasses was in the mixture of grey alder, averaging 5\%,0.67\% festulolium and $0.95 \%$ reed canary grass, although in all cases the $\mathrm{N}$ content was below the EU-standard critical limit, which means: the lower the nitrogen biomass, the lower the NOx emission quantity in the atmosphere.

Phosphorus (P), like potassium, when it is combusted, forms simple salts that are part of the ash composition.

The content of phosphorus, depending on the year and the species of cereal grasses, ranged from $0.20 \%$ for timothy and meadow fescue in 2012 to $0.47 \%$ for meadow fescue in 2013 . On average, from all the nitrogen fertilizer variants in the experiment, the phosphorus content of the meadow fescue was $0.34 \%$, reed canary grass and festulolium $-0.28 \%$, tall fescue $-0.27 \%$, and timothy $-0.26 \%$.

On the other hand, on average, from all nitrogen fertilizer variants, biomass phosphorus content was $0.35 \%$ ( $+9 \%$ compared to non-nitrogen fertilizer), festulolium $0.28 \%(+17 \%)$, reed canary grass $0.28 \%(-3 \%)$, but timothy and tall fescue $0.26 \%$ (-7\% and $-10 \%$ respectively).

Potassium (K) content is a significant indicator of the biomass quality, since alkali metals - potassium and sodium reduce the ash melting temperature, which in turn leads to the formation of slag layer on the walls of combustion chamber. 
The content of potassium, depending on the year and the species of grasses, ranged from $1.37 \%$ of the meadow fescue in 2012 to $3.69 \%$ of the meadow fescue in 2013. On average, from all the fertilizer variants of the experiment, the potassium content of the meadow fescue was $2.69 \%$, festulolium $-2.61 \%$, timothy $-2.52 \%$, tall fescue $-2.45 \%$, and reed canary grass $-2.21 \%$.

The correlation analysis showed that there is a slight positive correlation between $\mathrm{K}$ content in plants and fertilizer norm $(\mathrm{r}=0.31 ; p=0.1)$.

On average, from all the types of nitrogen fertilizer variants, biomass potassium content was $2.70 \%$ for meadow fescue, $2.66 \%$ for festulolium, $2.55 \%$ for timothy, $2.50 \%$ for tall fescue and $2.33 \%$ for reed canary grass.

Potassium content was more affected by meteorological conditions in a particular year. In 2012, in the intensive vegetation period of the grassland, when there was a lot of precipitation, potassium content in grass biomass, depending on the species, ranged from $1.37 \%$ in meadow fescue to $2.31 \%$ in tall fescue, but in the dry year of 2013 , from $1.95 \%$ of reed canary grass to $3.69 \%$ of meadow fescue. It only confirms the opinion of other researchers that increased soil moisture reduces accumulation of potassium in the tissues and may even rinse potassium from plants (Nutalapati, Gupta, Moghtaderi et al 2007).

Potassium content of cereal grasses with timber decreased systematically for both species. With $1 / 3$ of timber, the concentration of $\mathrm{K}$ decreased by $30 \%$ on average, but with a half and $2 / 3$, by $80 \%$ and $200 \%$, respectively.

Sulfur (S) is one of the undesirable elements, as it causes corrosion of heating equipment, and sulfur dioxide enters the atmosphere with flue gases. The sulfur content of plants, including grasses, is very variable.

In this study, sulfur content in cereal grasses ranged from $0.036 \%$ in 2012 to $0.180 \%$ in 2013 .

The sulfur content of cereal grasses biomass was on average about 4 times higher than in timber. In the timber and cereal grass mixture, the sulfur content was low, from $0.03 \%$ to $0.06 \%$. In most cases, the sulfur content of the blends decreased with the increase in the amount of timber. The lowest sulfur ratios for festulolium were in a mixture $(3 / 1 ; 1 / 1)$ with birch $(1 / 1)-0.031 \%$ and reed canary grass mix $(1 / 1)$ with hybrid aspen $-0.031 \%$.

Chlorine (Cl), like sulfur, causes corrosion of the equipment and releases $\mathrm{HCl}$, chlorinated dioxin, dibenzofuran and $\mathrm{Cl}$ precipitating salts in the ash (Rosendahl, 2013) going into the atmosphere with untreated flue gases.

The chlorine content of timber and cereal grasses in the samples was from $0.008 \%$ to $0.012 \%$ in timber and $0.50 \%$ to $0.74 \%$ in cereal grasses respectively. The chlorine content in the cereal grasses was 2.5 to 3.5 times the standard $0.2 \%$ limit (LVS EN 14961-6-2012). In its turn, chlorine content in timber was 1.5 to 2.5 times lower than the standard (LVS EN 14961-2-2011), set to $0.02 \%$. Chlorine content in cereal grass is significantly higher than in timber. In the 
cereal grasses, chlorine content ranged from $0.50 \%$ festulolium to $0.74 \%$ in reed canary grass. The lowest chlorine content in the timber was $0.008 \%$ for aspen, the highest for osier and birch $-0.012 \%$. In cereal grass and timber mixtures the chlorine content decreased as the amount of timber increased, as the $\mathrm{Cl}$ content varied more than 10 times between timber and cereal grasses.

The lowest chlorine content for festulolium was found in a mixture $(1 / 3)$ with birch $-0.18 \%$, reed canary grass with hybrid aspen $-0.25 \%$, tall fescue and timothy with grey alder $-0.22 \%$ and $0.17 \%$.

According to chlorine content, the lowest potential for the formation of slag is timber biomass, since its $\mathrm{Cl}$ content is lower. The contents of the mixture have lower mean values of $\mathrm{Cl}$ for festulolium and reed canary grass.

\section{Biomass Combustion Parameters}

The calorific energy from the fuel is characterized by the gross calorific value $\left(\mathrm{Q}_{\mathrm{a}}\right)$. For cereal grass biomass, the highest $\mathrm{Q}_{\mathrm{a}}$ value was found for timothy $-16.9 \mathrm{MJ} \mathrm{kg}^{-1}$, which is $1.2-2.3 \%$ less than that for hybrid aspen, which had the lowest heating value of all the timber biomass included in the study, or 9.6\% less than for birch, which had the highest $\mathrm{Q}_{\mathrm{a}}$ value. In contrast, the lowest $\mathrm{Q}_{\mathrm{a}}$ value was for tall fescue - 15.2 $\mathrm{MJ} \mathrm{kg}^{-1}$, which was $11.1-12.6 \%$ less than hybrid aspen and $18.7 \%$ less than birch. In mixtures of timber and cereal grasses biomass, the higher heating value increased with increasing proportion of timber in the mixture (Fig. 10). The highest heating value for a mixture ratio of $1 / 3(25 \%$ timber $+75 \%$ grasses $)$ was from $15.8 \mathrm{MJ} \mathrm{kg}^{-1}$ tall fescue mixture with aspen and hybrid aspen to $17.3 \mathrm{MJ} \mathrm{kg}^{-1}$ timothy mixture with osier, grey alder and birch, but for a mixture ratio of $3 / 1(75 \%$ timber + $25 \%$ grasses), the highest heating values were from $16.8 \mathrm{MJ} \mathrm{kg}^{-1}$ a mixture of tall fescue with a hybrid aspen to $18.3 \mathrm{MJ} \mathrm{kg}^{-1}$ timothy mixture with birch.

The correlation analysis revealed a significant $(p=0.01)$ negative calorific value correlation with the ash content $\left(\mathrm{R}^{2}=0.45\right)$ correlation with the ash content and $\mathrm{Cl}\left(\mathrm{R}^{2}=0.47\right)$, whereas the correlation with lignim was positive $\left(\mathrm{R}^{2}=0.46\right)$.

The melting point of the ash is characterized by four phases: the initial deformation temperature (DT), the start of melting (ST), the hemispherical point (HT), the flowing temperature (FT), when the ash flows over the surface. Among the cereal grasses, the highest DT was with reed canary grass $\left(1240^{\circ} \mathrm{C}\right)$, the others were from 1020 to $1120^{\circ} \mathrm{C}$. The timber biomass DT had boundaries from 1390 to $1460{ }^{\circ} \mathrm{C}$. The study evaluated the difference between the initial temperature of deformation of timber and grasses mixtures for biomass of timber and timber-grass mixture. It was found that adding reed canary grass to timber biomass reduced the biomass DT by only $14 \%$ on average. Adding 
timothy, festulolium and tall fescue to timber reduced the DT of the resulting mixture by $26 \%, 28 \%$ and $39 \%$, respectively.

The correlation analysis did not indicate the relationship between ash melting temperature and other specified parameters. The difference in the melting temperatures of the ash is explained by the chemical composition of the plants or individual elements which, due to high temperature, cause certain chemical reactions even within the same species (Kakīitis, Šmits, Belicka, 2009). It has been found that as the content of potassium increases, the ash melting temperature will decrease (Kalnačs, Grehovs, Grigale, etc., 2008).

\section{Energy Value of Biomass Fuel Raw Materials}

The amount of energy derived from the studied cereal grasses was directly dependent on yield. In 2012-2013, the highest amount of energy was obtained from grassland biomass ranging from $120.7 \mathrm{GJ}^{-1} \mathrm{ha}^{-1}$ (tall fescue) to $146.8 \mathrm{GJ}$ ha${ }^{1}$ (timothy), variant F $+\mathrm{N} 180$. In the absence of fertilizer, the amount of energy obtained from different cereal grass species varied from $49.0 \mathrm{GJ} \mathrm{ha}^{-1}$ meadow fescue to $67.2 \mathrm{GJ} \mathrm{ha}^{-1}$ reed canary grass. The amount of energy obtained from phosphorus and potassium fertilizers was from $69.3 \mathrm{GJ} \mathrm{ha}^{-1}$ meadow fescue $\left(+41 \%\right.$ in comparison with the control variant) to $79.3 \mathrm{GJ}^{-1} \mathrm{ha}^{-1}(+19 \%)$ for festulolium.

Nitrogen fertilizers contributed not only to the increase in dry matter yield, but also to the amount of energy produced. On average, the amount of energy received from all nitrogen-norm variants ranged from 103.5 $\mathrm{GJ} \mathrm{ha}^{-1}$ (tall fescue) to $126.8 \mathrm{GJ}^{\text {ha-1 }}{ }^{-1}$ (timothy) with an increase in the corresponding energy output from $33 \%$ to $64 \%$. The largest amount of energy was produced with osier on average in 2012-2013 (Fig. 11). Osier was blended with all types of cereal grasses in a ratio of $3 / 1(75 \%$ timber $+25 \%$ grasses $)$, i.e., with a predominance of timber and exceeding $140 \mathrm{GJ} \mathrm{ha}^{-1}$ (from $141.9 \mathrm{GJ} \mathrm{ha}^{-1}$ in tall fescue to 146.4 GJ ha ${ }^{-1}$ mixed with timothy). As the share of timber in the mix decreased, not only the gross calorific value decreased, but also the amount of energy produced.

\section{Production Costs of Biomass Fuel Raw Materials}

In this study, the agrotechnical methods of grasses were the same and comparable in order to evaluate their effect on the productivity of grasses and to find differences in nuances in different fertilizer variants. In turn, timber biomass production costs were obtained on the basis of literature references.

As the results of calculations show, on average, per year, the least expenditure on grass biomass was in the non-fertilizer application 
122.82 EUR ha-1 (Fig. 12), phosphorus and potassium (P80K120) fertilizer variant was $347.82 \mathrm{EUR} \mathrm{ha}^{-1}$ and in the variant with nitrogen fertilizer the costs of biomass was from $394.22 \mathrm{EUR} \mathrm{ha}^{-1}$ (with a nitrogen norm of $30 \mathrm{~kg} \mathrm{ha}^{-1} \mathrm{~N}$ ) to $551.20 \mathrm{EUR} \mathrm{ha}^{-1}$ (with a nitrogen norm of $180 \mathrm{~kg} \mathrm{ha}^{-1} \mathrm{~N}$ ). The use of fertilizers not only ensures increase in the dry matter yield, but also raises production costs.

In order to estimate the cost of timber for the dissertation work, for each type of timber, the highest values were applied, which were attributed to the life cycle of the respective wood production: for osier, hybrid aspen and grey alder, 20 years, and for birch 40 years as average values for 1 year, so that they could compare with the cost of production of grasses, because grasses are harvested every year, but wood only periodically. The management costs of grey alder were calculated from the average costs osier, birch and hybrid aspen. Based on this assumption, the total cost of the cycle for the production of energy timber biomass for osier was $6574.75 \mathrm{EUR} \mathrm{ha}^{-1}$ (average per year 328.74 EUR ha-1), birch - 7515.70 EUR ha-1 (average per year 187.89 EUR ha${ }^{1}$ ), hybrid aspen - 9891.50 EUR ha-1 (average per year $494.58 \mathrm{EUR} \mathrm{ha}^{-1}$ ) and grey alder - 6899.43 EUR ha-1 (average per year 344.97 EUR ha' ${ }^{-1}$ ).

Calculations show that the cereal grass and timber biomass analysed have a low cost of energy $\left(\leq 0.8\right.$ eurocents $\left.\mathrm{kWh}^{-1}\right)$. From the analysed timber, the highest cost of energy was for hybrid aspen $\left(0.8\right.$ eurocents $\mathrm{kWh}^{-1)}$ (Fig. 13), whereas the lowest was for birch ( 0.28 eurocents per $\mathrm{kWh})$. In turn, the energy cost of grasses was similar (from 0.69 to 0.74 eurocents per kWh) (Fig. 13).

The highest cost of energy was when phosphorus and potassium fertilizers were used to grow cereal grasses. Using phosphorus, the energy cost of biomass of $80 \mathrm{~kg} \mathrm{ha}^{-1} \mathrm{P}_{2} \mathrm{O}_{5}$ and potassium $120 \mathrm{~kg} \mathrm{ha}^{-1} \mathrm{~K}_{2} \mathrm{O}$ increased on average by 2.27 times (from 1.96 times for meadow fescue to 2.59 times for reed canary grass) compared to the control variant. Adding nitrogen to phosphorus and potassium fertilizers to the grass biomass decreased the cost of energy. A $20 \%$ reduction in the energy cost was detected in timothy starting from the nitrogen norm of $90 \mathrm{~kg} \mathrm{ha}^{-1} \mathrm{~N}$ and higher nitrogen norms compared to the non-nitrogen fertilizer variant. On the other hand, the cost of tall fescue, irrespective of whether small (30-60 $\left.\mathrm{kg} \mathrm{ha}^{-1}\right)$ nitrogen norms were used, or average (90-120 kg ha-1) or high (150-180 $\left.\mathrm{kg} \mathrm{ha}^{-1}\right)$, energy costs were similar to $0.12-0.13$ eurocents per $\mathrm{kWh}$.

For the production of mixtures of timber and grasses biomass, the lowest cost of energy was for an osier and birch mixture with cereal grasses ranging from 0.06 to 0.10 eurocents per kWh (Fig. 14).

The energy costs from grey alder and cereal grass mixtures ranged from 0.09 to 0.10 eurocents per $\mathrm{kWh}$, hybrid aspen mixed with cereal grasses of about 0.10 eurocents per $\mathrm{kWh}$, and for aspen mixtures with cereal grasses from 0.11 to 0.12 eurocents per $\mathrm{kWh}$. 
Summarizing the study results of the gross calorific value (Q) and energy costs of cereal grasses, the following trend was observed: the higher the calorific value, the cheaper the energy (Fig. 15).

The lowest cost price of energy was obtained from timothy $3.68 \mathrm{EUR} \mathrm{GJ}^{-1}$, which also had the highest calorific value $-16.88 \mathrm{MJ} \mathrm{kg}^{-1}$ from all the studied cereal grass species. A high calorific value was also obtained from festulolium - $16.46 \mathrm{MJ} \mathrm{kg}^{-1}$, which does not differ much from reed canary grass - 16.36 $\mathrm{MJ} \mathrm{kg}^{-1}$. The cost of the energy thus obtained was similar - 3.91 and 3.87 EUR GJ ${ }^{-1}$. The tall fescue and meadow fescue biomass had the lowest calorific value, 15.24 and $15.71 \mathrm{MJ} \mathrm{kg}^{-1}$, respectively, while the cost of energy was $13 \%$ and $19 \%$ higher than timothy (lowest cost of energy).

\section{CONCLUSIONS}

1. Nitrogen fertilizer, regardless of the size of the norm, increased the yield of dry matter for cereal grasses. In contrast, the effectiveness of nitrogen was different both between the grass species and between the years of use of the grassland. In all trial variants, the dry matter yield for cereal grasses was $6.08 \mathrm{t} \mathrm{ha}^{-1}$ on average during the first year of use, with $7 \%$ increase during the second year of use, $11 \%$ in the $3^{\text {rd }}$ year of use, $18 \%$ in the $4^{\text {th }}$ year of use, and $14 \%$ in the $5^{\text {th }}$ year of use compared to the first year of use. Differences in the efficiency of nitrogen fertilizer rates over the years of use of grassland are confirmed by the linear regression coefficients of polynomial distribution.

2. The highest dry matter yield from $1 \mathrm{~kg} \mathrm{~N}$ was obtained from cocksfoot grass and meadow fescue, on average, $60.44 \mathrm{~kg}$ and $28.96 \mathrm{~kg}$, respectively, when nitrogen norm was $30 \mathrm{~kg} \mathrm{ha}^{-1} \mathrm{~N}$. Conversely, using $60 \mathrm{~kg} \mathrm{~N}$ rate increased the dry matter yield of festulolium to $36.48 \mathrm{~kg}$, for timothy up to $30.50 \mathrm{~kg}$, reed canary grass up to $30.20 \mathrm{~kg}$ and tall fescue until $24.40 \mathrm{~kg}$.

3. The use of nitrogen from fertilizers for dry matter yield was $61.3 \%$, in timothy - on average in festulolium $-50.6 \%$, meadow fescue $-41.7 \%$, tall fescue $-28.0 \%$ nitrogen fertilizer norm $90 \mathrm{~kg} \mathrm{ha}^{-1}$ and reed canary grass $40.3 \%$ nitrogen fertilizer norm $60 \mathrm{~kg} \mathrm{ha}^{-1}$.

4. The highest yield of cereal grasses from $1 \mathrm{~kg}$ of NPK was obtained in the fertilizer variant N60P80K120: for cocksfoot grass $-34.7 \mathrm{~kg}$, for reed canary grass $-27.0 \mathrm{~kg}$, for festulolium $-26.6 \mathrm{~kg}$, for timothy $-26.1 \mathrm{~kg}$, for tall fescue $-25.8 \mathrm{~kg}$, and meadow fescue $-23.9 \mathrm{~kg}$.

5. In the $1^{\text {st }}$ year of grassland use, ash content in grasses did not exceed $8.92 \%$, but in the $2^{\text {nd }}$ year it did not exceed $7.91 \%$. The lowest ash content in the mixture of timber and cereal grasses in the proportion of 3/1 was osier with festulolium and reed canary grass $-2.30-2.63 \%$, for osier and birch with tall fescue $-2.5 \%$. 
6. The highest calorific value of cereal grasses was found from $15.24 \mathrm{MJ} \mathrm{kg}$ ${ }^{1}$ (tall fescue) to $16.88 \mathrm{MJ} \mathrm{kg}^{-1}$ (timothy). The highest calorific value $\left(\geq 18.0 \mathrm{MJ} \mathrm{kg}^{-1}\right)$ was found in biomass mixtures of birch and osier with reed canary grass, festulolium and timothy in a ratio of $3 / 1(75 \%$ timber + $25 \%$ grasses).

7. The highest ash melting temperature (DT) was detected with reed canary grass $\left(1240{ }^{\circ} \mathrm{C}\right.$ ), whereas the highest values (greater than $1100{ }^{\circ} \mathrm{C}$ ) for timber and cereal grass biomass mixtures were detected when reed canary grass, festulolium or timothy was added to timber.

8. The amount of energy produced for cereal grasses ranged from $93.6 \mathrm{GJ}$ ha ${ }^{1}$ (meadow fescue) to $112.1 \mathrm{GJ} \mathrm{ha}^{-1}$ timothy. The amount of energy produced from grass was on average $21 \%$ lower than that produced from timber. In the form of timber blends with cereal grasses, more energy was obtained from mixtures of tall fescue and timothy with timber in the proportion of $3 / 1$ ( $75 \%$ timber $+25 \%$ grasses $): 141.9-146.4 \mathrm{GJ} \mathrm{ha}^{-1}$.

9. For cereal grasses, the cost of energy varied from 0.69 to 0.74 eurocents per $\mathrm{kWh}$, but for timber from 0.28 eurocents per $\mathrm{kWh}$ birch to 0.8 eurocents per kWh hybrid aspen. For energy mixes of timber and grass biomass, the energy costs varied from 0.06 eurocents per $\mathrm{kWh}$ (for osier and birch timber blends with cereal grasses) up to 0.12 eurocents per $\mathrm{kWh}$ for aspen mixture with cereal grasses. The cost of energy for cereal grasses was also affected by fertilizer norms.

\section{PROPOSALS}

1. By expanding the range of using cereal grasses - not only the traditional use of fodder (green mass, hay, silage) but also for energy (biogas, fuel) and evaluating calorific characteristics of cereal grass biomass, the hypothesis was confirmed: grasses can be used as solid fuel raw materials that meet the requirements of standards in Latvia.

2. Since wood biomass is slowly growing and can be obtained periodically, but grassland biomass can be produced annually, using the potential of cereal grasses biomass can help to solve the demand for biomass resources (as raw material) for the production of heat energy.

3. In order to obtain fuel raw materials, it is advisable to form a mixture of cereal grasses and timber biomass with up to $25 \%$ of grass biomass.

4. The obtained calorific value characteristics indicate that the most promising cereal grasses for solid fuels are cocksfoot grass, reed canary grass, timothy and festulolium, therefore they are recommended to be used as an additive for the production of timber pellets. 


\section{PROMOCIJAS DARBA APROBĀCIJA / APPROBATION OF THE DOCTORAL THESIS}

Pētījuma rezultāti atspoguḷoti 14 zinātniskās publikācijās, kuras iekḷautas SCOPUS un/vai Web of Science datu bāzēs, un vienas konferences tēzēs. Par pētījuma rezultātiem ziņots 20 starptautiskajās zinātniskajās konferencēs.

Based on the research results 14 articles for SCOPUS and/or Web of Science indexed scientific journals have been prepared. The results of the research have been presented at 20 international scientific conferences.

\section{Zinātniskās publikācijas, kas indeksētas SCOPUS un/vai Web of Science datu bāzēs \\ Scientific papers indexed in SCOPUS and/or Web of Science data bases}

1. Platace R., Adamovics A., Ivanovs S., Gulbe I. (2017). Assessment of Ash Melting Temperature of Birch and Grass Biomass Pellet Mixtures. In: $16^{\text {th }}$ International Scientific Conference "Engineering for Rural Development": Proceedings. May 24.-26.05.2017, Jelgava, Latvia. Latvia University of Agriculture Faculty of Engineering, Vol. 16, p. 103-107.

2. Adamovics A., Platace R., Gulbe I., Ivanovs S. (2017). Influence of Fertilizers on Chemical Content of Energy Grass Biomass. In: $16^{\text {th }}$ International Scientific Conference "Engineering for Rural Development”: Proceedings. May 24.-26.05.2017, Jelgava, Latvia. Latvia University of Agriculture Faculty of Engineering, Vol. 16, p. 98-102.

3. Platace R., Adamovics A., Kalnacs J. (2016). Production of Reed Canary Grass-Wood Pellets. In: $15^{\text {th }}$ International Scientific Conference "Engineering for Rural Development": Proceedings. May 25.-27.05.2016, Jelgava, Latvia. Latvia University of Agriculture. Faculty of Engineering. Vol. 15, p. 371-374.

4. Adamovics A., Platace R., Ivanovs S. (2016). Influence of Nitrogen Fertilizers on Chemical Composition of Energy Grass. In: $15^{\text {th }}$ International Scientific Conference "Engineering for Rural Development”: Proceedings. May 25.-27.05.2016, Jelgava, Latvia. Latvia University of Agriculture. Faculty of Engineering. Vol. 15, p. 1085-1089.

5. Bumane S., Platace R., Poisa L., Adamovics A. (2016). Analysis of Reed Canary Grass Chemical Content. In: $15^{\text {th }}$ International Scientific Conference "Engineering for Rural Development": Proceedings. May 25.27.05.2016, Jelgava, Latvia. Latvia University of Agriculture. Faculty of Engineering. Vol. 15, p. 923-927.

6. Adamovics A., Platace R., Sivicka I. (2015). Influence of Nitrogen Fertilizer on Perennial Grass Dry Matter Yield and Suitability for Heat Production. In: Nordic View to Sustainable Rural Development: Proceedings of the 25th NJF Congress. June 16-18, 2015. Riga. Latvia, p. 
165-169. ISBN 978-9934-14-548-3 (printed); ISBN 978-9934-14-549-0 (electronic).

7. Būmane S., Poiša L., Čubars E., Platače R. (2015). The Analysis of Carbon Content in Different Energy Crops. In: Nordic View to Sustainable Rural Development: Proceedings of the 25th NJF Congress. June 16-18, 2015. Riga. Latvia, p. 156-160. ISBN 978-9934-14-548-3 (printed); ISBN 978-9934-14-549-0 (electronic).

8. Adamovics A., Platace R. (2015). Flue Gases Emitted by Timothy and Meadow Fescue Pellets. In: $14^{\text {th }}$ International Scientific Conference "Engineering for Rural Development": Proceedings. May 20-22, 2015, Jelgava. Latvia. Latvia University of Agriculture. Faculty of Engineering. Vol. 14, p. 536-540. ISSN 1691-5976.

9. Platace R., Adamovics A., Poisa L., Cubars E., Bumane S. (2015). Ash Content in Grass Biomass Yielded in 1st and 2nd Cultivation Year and Evaluation of Suitability Thereof for Pellet Production. In: $14^{\text {th }}$ International Scientific Conference "Engineering for Rural Development": Proceedings. May 20-22, 2015, Jelgava. Latvia. Latvia University of Agriculture. Faculty of Engineering. Vol. 14, p. 541-545. ISSN 1691-5976.

10. Platace R., Adamovics A. (2014). Indicators Characterising Calorific Value of Reed Canary Grass and Last Year's Grass. In: $13^{\text {th }}$ International Scientific Conference "Engineering for Rural Development": Proceedings. May 29-30, 2014, Jelgava, Latvia. Latvia University of Agriculture. Faculty of Engineering. Vol. 13, p. 440-443.

11. Platace R., Adamovics A. (2014). Content of Lignin and Ash in Grass Biomass Depending on Fertiliser Type and Rate. In: $13^{\text {th }}$ International Scientific Conference "Engineering for Rural Development": Proceedings. May 29-30, 2014, Jelgava, Latvia. Latvia University of Agriculture. Faculty of Engineering. Jelgava, 2014. Vol.13, p. 444-449.

12. R. Platače, Adamovičs A. (2014). The Evaluation of Ash Content in Grass Biomass Used for Energy Production. In: WIT Transactions on Ecology and the Environment. Vol. 190 (2): Proceedings of the 1st International conference "Energy production and management in the 21st century: the quest for sustainable energy", p. 1057-1065.

13. Platače R., Adamovičs A. (2013). Evaluation of Ash Content Grass Plant Biomass used for Energy. In: The 6th International Scientific Conference "Rural Development 2013: proceedings. 28-29 November, 2013, Akademija, Kaunas district, Lithuania. Aleksandras Stulginskis University. Vol. 6: Innovations and sustainability, book 3, p. 114-118. ISSN 23450916

14. Platace, R., Adamovics, A., Gulbe, I. (2013). Lignocellulosic Biofuels and Grass Plants Used in Production of Pellets. In: The International Scientific Conference "Environmental and Climate Technologies 2013" proceedings, 
October 14-16, Institute of Energy Systems and Environment of Riga Technical University, p. 66-71.

\section{Ziņojumi starptautiskajās zinātniskajās konferencēs un kongresos. Reports at international scientific conferences and congresses.}

1. Platače R, Adamovičs A. (2018). Mēslojuma ietekme uz zālaugu sausnas ražu, biomasas kvalitāti un augu barības elementu iznesi. / Influence of fertilizer on grass dry matter gain, quality of biomass and depletion of plant nutrition elements. Lìdzsvarota lauksaimniecība, Zinātniski praktiskās konferences tēzes, Jelgava, LLU, Latvia. [in latvian]

2. Platace R., Adamovics A., Ivanovs S., Gulbe I. (2017). Assessment of Ash Melting Temperature of Birch and Grass Biomass Pellet Mixtures. $16^{\text {th }}$ International Scientific Conference "Engineering for Rural Development". May 24.-26.05.2017, Jelgava, Latvia.

3. Poisa L., Adamovics A., Platace R. (2017). Evaluation of chemical content in different energy crops. Rual Development 2017: Bioeconomy challenges. $8^{\text {th }}$ international scientific conference. $24^{\text {th }}$ November, 2017, Aleksandras Stulginskis Universitity, Akademija, Kaunas district, Lithuania.

4. Adamovics A., Platace R., Gulbe I., Ivanovs S. (2017). Influence of Fertilizers on Chemical Content of Energy Grass Biomass. $16^{\text {th }}$ International Scientific Conference "Engineering for Rural Development”. May 24.-26.05.2017, Jelgava, Latvia.

5. .Poisa L., Bumane S., Cubars E., Platace R. (2017). Evaluation of Sulphur Content in Different Energy Crops. In: $16^{\text {th }}$ International Scientific Conference "Engineering for Rural Development": Proceedings. May 24.26.05.2017, Jelgava, Latvia.

6. Platace R., Adamovics A., Kalnacs J. (2016). Production of Reed Canary Grass-Wood Pellets. 15th International Scientific Conference "Engineering for Rural Development”. May 25.-27.05.2016, Jelgava, Latvia.

7. Adamovics A., Platace R., Ivanovs S. (2016). Influence of Nitrogen Fertilizers on Chemical Composition of Energy Grass. 15 th International Scientific Conference "Engineering for Rural Development". May 25.27.05.2016, Jelgava, Latvia.

8. Bumane S., Platace R., Poisa L., Adamovics A. (2016). Analysis of Reed Canary Grass Chemical Content. 15 $5^{\text {th }}$ International Scientific Conference "Engineering for Rural Development". May 25.-27.05.2016, Jelgava, Latvia.

9. Adamovics A., Platace R., Sivicka I. (2015). Influence of Nitrogen Fertilizer on Perennial Grass Dry Matter Yield and Suitability for Heat Production. Nordic View to Sustainable Rural Development. $25^{\text {th }}$ NJF Congress. June 16-18, 2015. Riga, Latvia. 
10. Būmane S., Poiša L., Čubars E., Platače R. (2015). The Analysis of Carbon Content in Different Energy Crops. Nordic View to Sustainable Rural Development. $25^{\text {th }}$ NJF Congress. June 16-18, 2015. Riga, Latvia.

11. Adamovics A., Platace R. (2015). Flue Gases Emitted by Timothy and Meadow Fescue Pellets. $14^{\text {th }}$ International Scientific Conference “Engineering for Rural Development". May 20-22, 2015, Jelgava, Latvia.

12. Platace R., Adamovics A., Poisa L., Cubars E., Bumane S. (2015). Ash Content in Grass Biomass Yielded in $1^{\text {st }}$ and $2^{\text {nd }}$ Cultivation Year and Evaluation of Suitability Thereof for Pellet Production. 14 ${ }^{\text {th }}$ International Scientific Conference "Engineering for Rural Development”. May 20-22, 2015, Jelgava.

13. Platace R., Adamovics A. (2014). Indicators Characterising Calorific Value of Reed Canary Grass and Last Year's Grass. 13 $3^{\text {th }}$ International Scientific Conference "Engineering for Rural Development". May 29-30, 2014, Jelgava, Latvia.

14. Platace R., Adamovics A. (2014). Content of Lignin and Ash in Grass Biomass Depending on Fertiliser Type and Rate. 13 ${ }^{\text {th }}$ International Scientific Conference "Engineering for Rural Development". May 29-30, 2014, Jelgava, Latvia

15. Platače R., Adamovičs A. (2014). The Evaluation of Ash Content in Grass Biomass Used for Energy Production. 1st International Conference on Energy Production and Management in the $21^{\text {st }}$ Century: The Quest for Sustainable Energy. 23 - 25 April, 2014, Ekateringburg, Russian Federation.

16. Platače R., Adamovičs A. (2013). Evaluation of Ash Content Grass Plant Biomass used for Energy. The 6th International Scientific Conference "Rural Development 2013. 28-29 November, 2013, Akademija, Kaunas district, Lithuania.

17. Platace R., Adamovics A., Gulbe I. (2013) Evaluation of Factors Influencing Calorific Value of Reed Canary Grass Spring and Autumn Yield. 12th International Scientific Conference "Engineering for Rural Development". May 23-24, 2013, Jelgava, Latvia.

18. Platace R., Adamovics A., Gulbe I. (2013). Assessment of factors influencing potassium content in reed canary grass/poplar pellets and grass plants. 13th International Multidisciplinary Scientific GeoConference \& EXPO - SGEM 2013 "Energy and Clean technologies". June 16-22, 2013, Albena, Bulgaria.

19. Platace, R., Adamovics, A., Gulbe, I. (2013). Lignocellulosic Biofuels and Grass Plants Used in Production of Pellets. Conference Proceedings of the International Scientific Conference "Environmental and Climate Technologies 2013" October 14-16, Riga Technical University. 